\title{
The Sustainability of Industrial Heritage Tourism Far from the Axes of Economic Development in Europe: Two Case Studies
}

\author{
Xosé Somoza-Medina ${ }^{1, *(D)}$ and Obdulia Monteserín-Abella ${ }^{2}$ (D) \\ 1 Department of Geography and Geology, University of León, 24071 León, Spain \\ 2 Department of History, Geography and Art, University of Jaume I, 12071 Castelló de la Plana, Spain; \\ monteser@uji.es \\ * Correspondence: somoza@unileon.es
}

check for updates

Citation: Somoza-Medina, $\mathrm{X}$; Monteserín-Abella, O. The Sustainability of Industrial Heritage Tourism Far from the Axes of Economic Development in Europe: Two Case Studies. Sustainability 2021, 13, 1077. https://doi.org/10.3390/ su13031077

Academic Editors:

Carmen Hidalgo-Giralt and

Antonio Palacios-Garcia

Received: 2 December 2020

Accepted: 18 January 2021

Published: 21 January 2021

Publisher's Note: MDPI stays neutral with regard to jurisdictional claims in published maps and institutional affiliations.

Copyright: (c) 2021 by the authors. Licensee MDPI, Basel, Switzerland. This article is an open access article distributed under the terms and conditions of the Creative Commons Attribution (CC BY) license (https:/ / creativecommons.org/licenses/by/ $4.0 /)$.

\begin{abstract}
The transformation of mining and industrial spaces into tourist spaces is part of the debate surrounding the profound changes in the contemporary economies of developed European countries. The loss of competitive power of their traditional companies, the obsolescence of many manufacturing facilities, and the take-off of other industrial economies in remote parts of the world have led to the closure of thousands of mines and factories, with the approval of environmental groups. In some privileged places, these ex-industrialized spaces have recovered environmentally, been allocated aid for socio-economic reconversion, and reoriented the old mines and factories (now converted into industrial heritage), towards cultural and tourist uses. The successful examples of Ironbridge, Zollverein or Wieliczka, have created the illusion to managers, owners, and local population of being able to turn almost any ruin of the industrial and mining past into a tourist attraction. Starting in the 1990s, many ex-industrial spaces, which were far from the main urban centres, opted for this tourist transformation as a lifeline to slow down the loss of population and economic activities. Sometime after these projects of industrial tourism, the result can be evaluated with objective data that question the sustainability of the model and the resilience of these places. This paper focuses on questioning the sustainability and resilience of the tourist transformation of two former mining areas located in Spain (Almadén and Sabero), far from the axes of economic development.
\end{abstract}

Keywords: industrial heritage tourism; European Route of Industrial Heritage; mining parks and museums; sustainability; ex-industrial spaces

\section{Introduction}

Modern society adheres to very different ethical values compared to those that influenced the social norms and customs of previous eras. Today, for example, sustainability is an ethical principal that connects generations and which we must always take into account in the evaluation of any activity that transforms the in which space we live. Many centuries ago, power was demonstrated by building monumental edifices in highly visible locations, such that the population, seeing the ziggurat, the castle, or the cathedral, would know that true power lay within its walls. Nowadays, most of us, when we see large construction projects taking shape on wasteland, the first thing we ask is whether this, whatever it is, is sustainable.

Sustainability embraces everything and allows us to establish a new value scale in which cost, aesthetics and originality are not the essential factors when judging a project, but rather its potential to survive through time, without altering the environment. Sustainability has gone viral, and its message resonates in every corner of the planet, even where the messenger is but a youngster whose only power is in their voice. Other changes that have come to characterise modern society, and contrast with the ways of life in bygone times, is the importance we give to our leisure time activities. Tourism continues to establish new records despite various crises in the economy, politics, and health. Although, regarding this last point, it is possibly still too early to evaluate the real consequences to 
tourism of the coronavirus disease 2019 (COVID-19) pandemic. Whatever the case, it must be supposed that, sooner or later, we will be looking at a figure for global travel due to tourism that is, once again, setting new records.

Tourism, as a global phenomenon, did not become relevant until the last decades of the 20th century, when the increase in recreational travel became sufficiently large that any location possessing any attraction might be turned into a potential tourist destination for at least one of the many segments of the tourism market. Since then, we have been able to talk about rural, urban or nature tourism; coastal or interior tourism; luxury tourism or backpacking; literary, architectural, war, dark or grief tourism; ornithological, religious, sex, gastronomic, heritage, conference, cultural, sports, magic, ethnographic, fashion, cinema, adventure, shopping, alcohol, cemetery, health, and events tourism; tourism for seniors, kids, teens, families, or the LGBT community; and also, industrial tourism.

Industrial heritage tourism is characterised by presenting the industrial heritage of a certain location as an attractive feature. Industrial heritage includes mines, factories, administrative buildings, workshops, housing, communications infrastructure, and heavy machinery, in addition to commercial products, business documentation, tools, vehicles, clothing and even the everyday foods of that glorious past. A past which will have had huge value in terms of socioeconomics and identity, thereby justifying its resurrection and reinterpretation in the present.

After the successful examples of Ironbridge, Zollverein, New Lanark, Geselkirchen and Wieliczka in Europe or Lowell and Birmingham in the USA, hundreds of places have found new uses for old, disused mines and factories [1,2]. All these projects have taken a similar model based on joint endeavours between a private industrial heritage preservation foundation, politicians, and local government. They used campaigns on various communication media platforms and public subsidies, with the end result being the creation of new eco-museums and heritage parks that have all contributed to an increased global offering in industrial heritage tourism.

The first step motivating the creation of industrial heritage is disuse. While factories and mines remain active, industrial complexes are not considered as heritage; they are fixed assets. In this way, due to the cycle of major industrial crises and restructuring, many manufacturing facilities are abandoned, creating huge land holdings that can be disposed of in several different ways. When obsolete factories or transport hubs are located within the urban core, what usually happen, especially in dynamic cities, is a process of clean up and the building of new, remodelled neighbourhoods with innovative architecture, leaving a few elements of industrial heritage as some form of memento of the past. Ex-industrial land on the edges of urban development, however, can often be left in disuse for many decades, waiting in the hope that housing demand and planning laws allow the recategorization of the land to the benefit of its owners. Lastly, when industrial spaces are very far from urban centres and through their operation over decades have caused irreversible changes to the landscape, they are permanently abandoned, re-purposed for tourism and recreation, or transformed into other uses (residential, commercial, public services).

According to the Spanish National Plan for Industrial Heritage, industrial heritage is defined as that collection of assets, both moveable and unmoveable, and the social systems related to working class culture which have been generated through activities of extraction, transformation, transport, distribution, and management and which came into being as a result of the economic system founded in the Industrial Revolution. This definition is sufficiently broad that almost any disused mine or manufacturing centre that may be found can be converted into a tourist attraction.

The question that we need to pose is, then, whether any proposed new eco-museum or industrial heritage museum is sustainable, especially in economic and ecological terms. In other words, can the investment required to convert any given ex-industrial site into tourism-recreational infrastructure and maintain its future use over time be justified economically and environmentally? To answer this research question, we will take two case studies, both disused industrial mining sites that have been converted into heritage parks in 
areas far from major cities. These examples are at the periphery of European development and at the outer borders of Spain. However, these two case studies are both categorised as "Anchor Points" in the European Route of Industrial Heritage (ERIH), and as such they have been awarded quality certificates as industrial tourism destinations.

\section{The Industrial Heritage Trail, ERIH, and Anchor Points}

The regions of Europe that experienced the greatest economic and industrial development over the 19th and at the beginning of the 20th centuries are those that have accumulated the greatest number of industrial heritage sites: South Wales; the Black Country and Yorkshire, in England; Strathclyde in Scotland; the Ruhr and Saar in Germany; Alsace, Nord-Pas de Calais and Lorraine in France; Wallonia in Belgium; Veneto and Lombardy in Italy; Catalonia, Asturias and the Basque Country in Spain; Silesia and Lodz in Poland; and Karvina-Ostrava in the Czech Republic. All these territories have promoted the regeneration of their industrial heritage through museumization and the creation of visitor centres that, in due course, have begun to forge links with each other to set up so-called industrial tourism routes [1]. The most important of these was established in the Ruhr, Germany, and many years later, it became the model for the European Route of Industrial Heritage.

The Industrial Heritage Trail (Route der Industriekultur) in the Ruhr region was established as the result of a process, initiated in 1988, through a regional government initiative in North Rhine Westphalia, whereby abandoned industrial spaces were regenerated and reused [3]. The 1980s was a watershed decade for many traditionally industrial regions, immersed in a wide-reaching modernisation crisis that had a huge impact on employment in the secondary sector with the closing of a large number of businesses. As a solution, in many regions, alternatives were sought connected with culture and the tertiary sector, specifically the leisure industry [4]. In this way, spaces that were previously characterised by long working hours were now converted to offer hours of leisure time to their potential users. Due to this growth in the service sector, the territorial dynamics of whole regions were altered. Factories and workshops were transformed into museums, art galleries or concert halls; mines into parks and auditoriums; transport arteries into green corridors; and all this after an open process of ideas exchange to find the best solution. In Germany, this model came about through the experience of the Emscher Park IBA (Internationale Bauaustellung) project, a ten-year programme (1989-1999), financed through local, regional and national governments, with additional European grants, and in consultation with architectural and planning working parties to assist in plotting the way forward for these historic industrial zones [5]. In this way, an extensive area in the centre of the Ruhr region was regenerated according to a common set of guiding principles: ecological restoration of rivers and spoil heaps, reduction in environmental impact, consideration of the landscape, restoration of industrial heritage as a symbol of territorial identity, and the social reintegration of the long term unemployed. The Ruhr region, with a population density of 2800 inhabitants $/ \mathrm{km}^{2}$, is a polycentric and dynamic urban area, well connected with other important and developed European regions. The objective was to regenerate the area such that it could be, once again, a centre for new industrial initiatives based on design and innovation [3]. Throughout the last decade of the 20th century, Germany saw the number of regeneration projects increase; this was especially so in Ruhrgebiet, where the Regionalverband Ruhr association of 53 cities, became a major instigator [6].

The Industrial Heritage Trail itself was commissioned by the Regionalverband Ruhr and set up in 1999, as a direct result of the Emscher Park IBA initiative. Connecting the major tourist attractions within this region of Germany, the trail comprises a circular route of $400 \mathrm{~km}$, passing through 52 different locations of interest: 25 emblematic attractions, termed Anchor Points; 14 industrial landscape parks; and 13 workers' settlements (see Figure 1). Amongst these places, we find, Zeche Zollverein, a heritage park on the site of a disused coal mine and Landschaftspark Duisburg-Nord, the industrial landscape park at Duisburg. The trail is signposted uniformly, offering tourist information about all the 
Anchor Points; walks around attraction parks marked with information panels; sculptures and other artistic installations; a coordinated calendar of cultural events; and a series of offers and benefits as part of a comprehensive tourist package. The trail can be followed in full or following a specific themed route: visiting all the industrial attractions in a particular city; or those associated with the different branches of industry or mining; or only principal eco-museums and heritage parks.

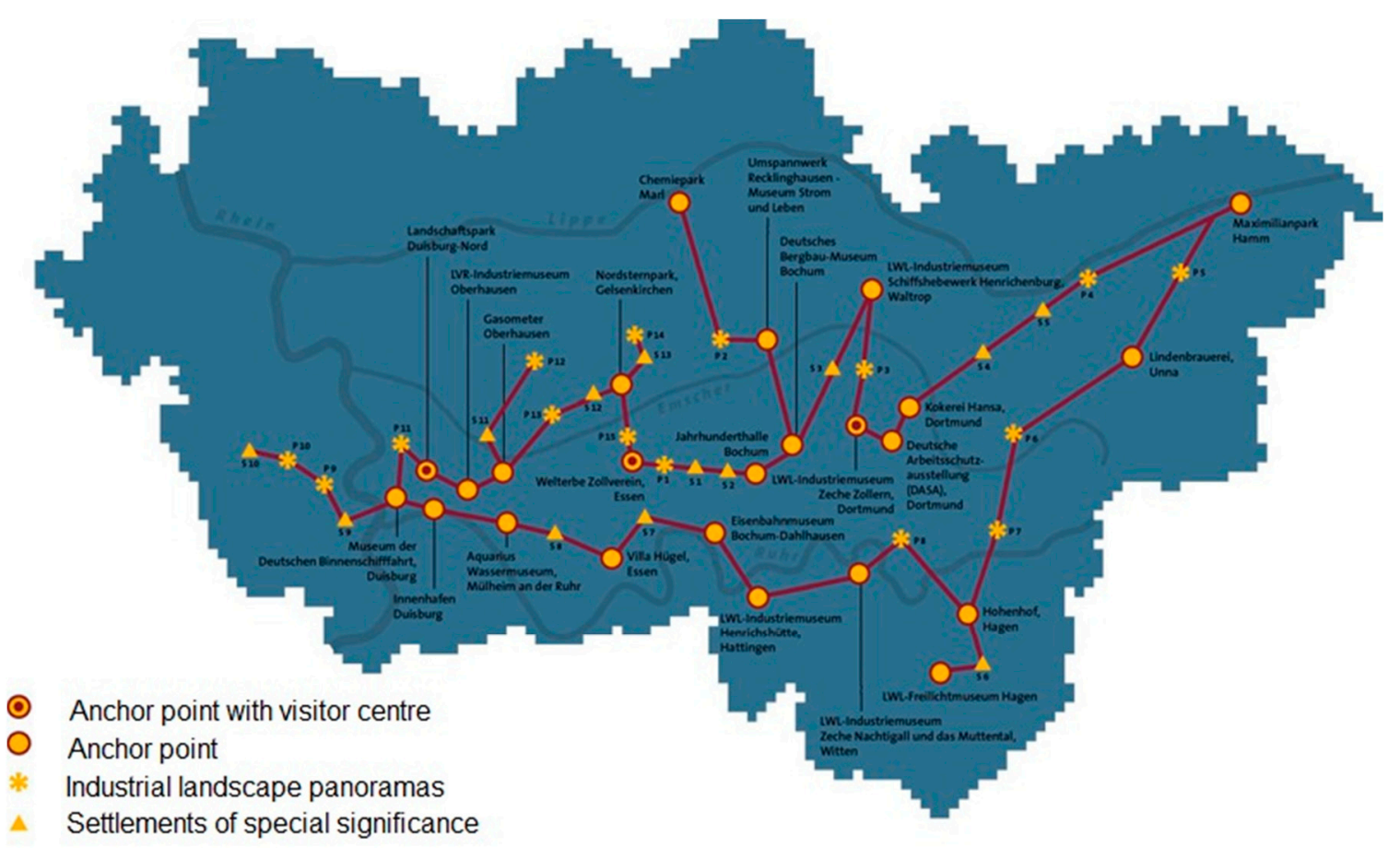

Figure 1. The Industrial Heritage Trail. Source: http:/ / www.route-industriekultur.ruhr/.

The Emscher Park IBA project received some criticism concerning the limited number of new jobs it created, contrary to initial goals, and the emphasis given to elitist, symbolic projects that did not offer real solutions to the severe social problems experienced by the region [7]. Since the inception of the Emscher Park IBA project in 1989, the region has experienced two distinct phases of recovery-regeneration. The first two decades were characterised by measures aimed at the reuse of industrial heritage for tourism and cultural purposes funded by public money, while more recently, projects involving reindustrialisation and property development have been prioritised [7]. Although the region's population has decreased since the 1960s (from 5.7 million to 5.1 million), statistics have shown a slight growth since 2016.

Whatever the case, the tourist-recreational Industrial Heritage Trail promptly became an example of success. Other European regions attempted to repeat the model in their own former industrial areas, with projects appearing in Flemish regions of Belgium, in Alsace and northern France; Asturias in Spain; Silesia in Poland; the Saar-Lor-Lux Euregios between Germany, France and Luxembourg; in Maas-Rhine between the Netherlands, Belgium and Germany; and in other more far-flung regions such as the Czech Republic and Norway [8].

The universalization of industrial heritage restoration projects in Europe allowed the promotion of a European-wide heritage route, taking the German trail as its model. Between 2002 and 2007, the German state (or Länder) of Rennania in North Rhine-Westphalia, the most densely populated, led the project whose objective, as part of the Interreg II programme, was the creation of a European industrial heritage tourist information network. This network was designed to show off the diversity of European industrial history and its common roots, and initially counted on the involvement of regions of the United 
Kingdom and the Netherlands, with regions from other countries joining in later [6]. As with the trail in Ruhr, the European Route of Industrial Heritage (ERIH) is structured around Anchor Points, themed routes, and a multilingual web-portal containing abundant geo-specific information. Today (2020), the route boasts 2000 industrial heritage sites in 50 different European countries; 113 of these are denominated as Anchor Points and there are 20 regional routes plus 16 transnational routes. The underlying idea behind the ERIH is that some of the experiments in regenerating huge swathes of ex-industrial land tested out in Ruhr might also be successful in other parts of Europe [9].

The selection of points of interest for the ERIH is related to the facilities and services available in those places and their ability to attract tourists. Moreover, those locations considered to be Anchor Points must comply with a specific set of requirements. According to the ERIH website (www.erih.net), an Anchor Point must be an authentic site of historic interest with a symbolic value and importance in European industrial history. It must also display an imaginative interpretation of its history through its exhibitions; offer its visitors modern and attractive facilities; use other nearby locations for cultural events and other attractions; and meet the expectations of its visitors in terms of infrastructure and innovative tourist services. The Anchor Points are considered the most high-profile attractions on the route, the standard bearers for the ERIH brand, and as such, they have a responsibility not to disappoint their visitors.

\section{Theoretical Framework}

Sustainability and resilience are terms taken from the study of nature but can also serve to explain processes of social change. Both terms are used to describe the conditions under which a place - an environment-can remain in a specific state (sustainable and/or resilient). The first of these terms, sustainability, from its roots as a term associated with ecology, came to be widely used in the 1970s at international conventions promoted by public bodies (the United Nations_Stockholm, 1972; the European Community—Paris, 1972). It established itself in the new world paradigm of "sustainable development" after the United Nations report "Our Common Future" in 1987 (the Brundtland Report) and later the Rio Summit in 1992, also promoted by the UN. Since then, sustainable development has been seen as an ideal to which to aspire, providing for the needs of the present generation without compromising the ability of future generations to provide for themselves. This concept is structured around three pillars: economic development, social development, and protecting the environment.

Resilience, in physics, is the capacity for a material, mechanism or system to recover its initial state after being subjected to some perturbation. One of the first scientists to relate resilience and sustainability was the Canadian ecologist, C. S. Holling, who established that the resilience of a socio-ecological system was its capacity to tolerate perturbation and counteract the resulting entropy, in such a way that, after experiencing a disturbance, it could evolve from its initial state towards one of multiple new equilibrium states without encountering a crisis point [10].

There are several obvious links between sustainable development and resilience. To achieve one, we must base our actions on the other. The most resilient environments are those that display the capacity to adapt to circumstances and as yet unknown risks, therefore ensuring sustainability [11].

The crisis in traditional industry saw numerous regions suffering severe restructuring processes, with the loss of thousands of jobs, and the abandonment of hundreds of mining and other industrial facilities. These regions experienced ongoing economic deterioration due to the collapse of the industrial activity upon which millions of people depended. In this context, the regeneration of these regions began, with the injection of massive public funds to finance restoration projects where ecology, culture and social regeneration all played key roles. These projects gave birth to another novel concept, that of industrial heritage. In this way, abandoned buildings, mines, canals, facilities, and worker's housing 
were converted into historic monuments, the symbols of a lost regional economy that needed to be preserved for the edification and enjoyment of future generations.

In Spain, the development of industrial heritage as part of the new tourism and leisure industry has been a focus of analysis for some time [12-20]. This analysis has tended to highlight the positive elements that have resulted from regeneration where such processes have taken place.

On the other hand, the European Charter for Sustainable Tourism, considers as fundamental both the conservation and improvement of heritage, either natural, historic, or cultural, and indeed the promotion of activities related to local identity and history-the latter being highlighted when due attention is paid to the important role of the population and local initiatives in models of sustainable tourism. In this vein, Pardo [17] maintains that sustainable tourism in the field of industrial heritage is that directed at guaranteeing the use and conservation of this heritage as a cultural resource, with the support and participation of visitors and the local community, and whose aim is to minimise any adverse impacts while maximising the social, economic, cultural, and environmental benefits from tourism.

Jansen-Verbeke [21] proposes even more stringent conditions when exploring how the development of sustainable industrial tourism should aim to balance the needs of tourists against those of the regions being visited, protecting both heritage sites and also promoting the opportunities for future development. The management of tourist resources in this field should not be constrained to mere recreational contemplation, but also generate an environment for innovation and progress [21].

Other authors highlight the weak sustainability of industrial heritage tourism, due to the lack of commitment of the local population in the transformation of a productive space into a cultural space [22], or because of its low economic profitability [23]. In the survey conducted by Denise Cole in 2002 in 45 U.K. mining heritage attractions, only 7.5\% declared "comfortable profit", while $37.5 \%$ depended on public subsidies and $55 \%$ were "breaking even" [23].

With the worldwide changes that have occurred as a result of the COVID-19 pandemic, the fact that we live in a society full of risks is more clearly demonstrated than ever. As a result, the conceptual framework to which we should orient ourselves is defined by the search for sustainable development as a way of constantly improving society through the fostering of a local resilience that promotes innovation and progress in the context of ongoing risk and unforeseen circumstances. In this sense, questioning the sustainability and resilience of a tourism transformation process in rural areas will allow offering relevant information for future developments.

\section{Methodology}

As a result of the industrial decline associated with the extractive activity of coal and cinnabar due to the level of contamination of the activity and the loss of competitiveness in the international market, a debate has arisen around the resilience capacity of peripheral territories searching alternatives for development.

Although the economic crisis that affects many industrial areas occurs on an international scale, this research focuses on the Spanish case. Spain has registered a strong loss of the weight of the industry in the economy. The value of GDP in industry has decreased, from representing $25.9 \%$ in 1980 to $14.02 \%$ in 2020 [24]. These data are below the GDP of the rest of Europe.

While industrial activity has lost weight in national GDP, the value of GDP in tourism has been on the rise until 2020, reaching $12.4 \%$ in 2019 [24]. Taking into account the relationship between tourism and economic growth in general terms as shown by some studies [25], the general objective of the research is to analyse the functional dynamics of two territories with an industrial tradition in peripheral areas.

The heritage valorisation process, based on the inscriptions in the different heritage protection figures, and the level of tourism functionality, constitute variables for the study of the sustainability of tourism activity. The sustainability of industrial tourism is understood 
here in its economic dimension. This is related to the ERIH's ability to promote synergies at a local-regional and international level.

Not all tourist destinations and products have the same impact on the economy or on the behaviour of visitors, but it has been possible to observe the increase in the local cultural often associated with industrial heritage as a basic element of the tourism system in question [25].

The research focuses on industrial tourism associated with the cultural-industrial tourism modality [26]. It will be defined by the motivation of the tourist flows: motivated by tourist resources related to the visit to mining industrial facilities related to both the Living Industry included in the UNE 302001: 2016 Standard, as well as historical, because in the case of Almadén and Sabero, the industrial activity is non-existent at present.

Among the various conceptual meanings of industrial tourism and industrial heritage tourism, we take as a reference the notion of industrial heritage tourism, consisting of museums and eco-museums, factories and industrial facilities, industrial routes, and interpretation centres [27]; the real, movable and intangible industrial assets included in the National Plan for Industrial Heritage, and the notion of industrial tourism understood as that which offers experiences related to the knowledge of making a product, the history or tradition, and industrial heritage [28].

The study focuses on carrying out an approximation on the management capacity of industrial complexes, trying to interpret the results in the European context of tourist activity in spaces equipped for visits, without differentiating those that still register industrial activity.

The analysis of tourist flows constitutes an indicator of approximation to the capacity for self-management, rather than trying to assess the incidence of the patrimonial valuation of the elements by the different organizations.

The analysis is based on the European scale, and specifically the ERIH territory, because Almadén and Sabero are part of this route.

This work is divided into three parts. The first part contains a review of the current literature on industrial tourism and an examination of successful experiences in Europe that constitute examples of good practice for the integration and reuse of ex-industrial space for new, productive activities related to culture and leisure. The regeneration of many of these spaces as tourist attractions can be profiled as the application of the principles of resilience and sustainability to combat their decline.

In the second part, the theoretical framework underlying the investigation is explained. This framework is defined principally by the context in which industrial tourism develops, and its relationship to medium- and long-term resilience and sustainability.

The third section, containing case studies of two Anchor Points, will enable a discussion of the viability and sustainability of industrial tourism in the environs of Almadén and Sabero (Figure 2). These two places were chosen as Anchor Points representative of rural spaces far from the axes of urban and economic development.

In addition to bibliographic and documentary sources, the sources used for the case study focused on the global results of the ERIH Barometer for 2018 and 2019 for the entire ERIH territory, although it was possible to have disaggregated data only in the case of Almadén, and data available from MAYASA [29] and the Junta de Castilla y León in the case of Sabero. The results of the ERIH Barometer, disaggregated in the case of Almadén, were compared with those provided by the MAYASA visitor study and the general results were used for the discussion where a comparison of the cases with the European ERIH context could be made.

The ERIH Industrial Heritage Barometer in 2019 shows some methodological differences between 2018 and 2019; however, the results have been generalized. The survey covers questions on a variety of topics related to industrial heritage and is directed at those responsible for industrial heritage sites. It is carried out online by ERIH, an association registered in Germany, in cooperation with Regionalverband Ruhr. There are a total of 12 questions, which focus on the management and financing characteristics of the 
site, the profile of the visitor, manager satisfaction, and on the medium-term objectives and strategies.

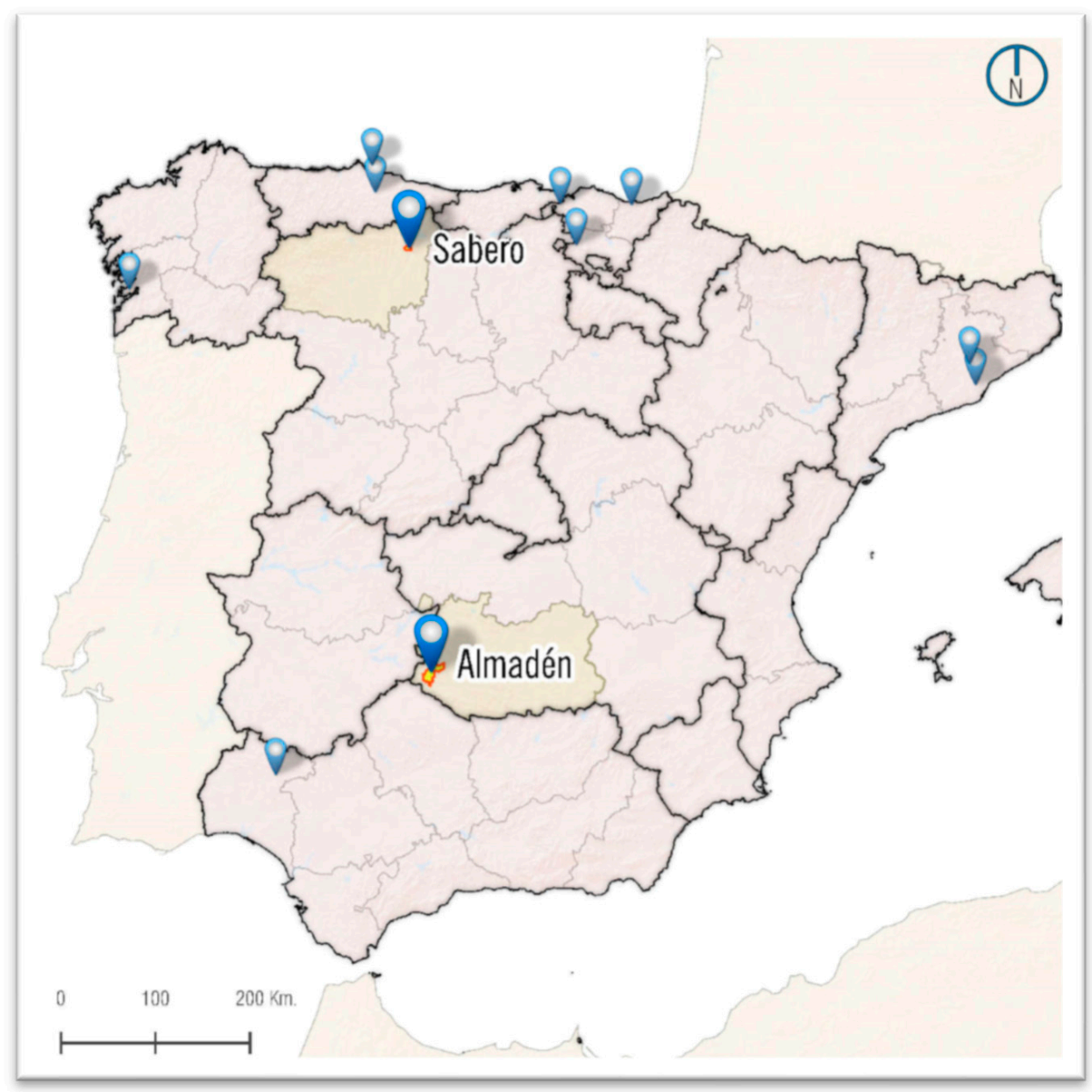

Figure 2. European Route of Industrial Heritage (ERIH) Anchor Points located in Spain.

For the case study, sources from the companies and managing bodies of the site have been used. This is the case of MAYASA and the Junta de Castilla y León.

The two case studies have a series of common characteristics: geographic extent; considerable environmental impact of the industry that has not been restored; changing and declining population density; industrial decline; and a significant level of isolation from other centres of economic development. Data for the analysis and discussion of the tourism strand of redevelopment in these locations were provided by the industrial heritage management bodies of each location and extracted from the ERIH Industrial Heritage Barometer, a statistical metric produced by the Regionalverband Ruhr since 2018.

The case studies give rise to many questions for discussion, concerning themes surrounding the sustainability of industrial tourism in outlying regions. These are brought together in the conclusion.

\section{Case Studies}

\subsection{Almadén}

The municipality of Almadén is located in the Alcudia valley, and forms part of the eight municipalities comprising the Montesur Association. This association was constituted in 1996 to enable the management of rural development programmes. This group of municipalities in Montesur is a non-administrative district on the peripheries of the Iberian Peninsula and has a population of 11,142 [30]. At the district level, the population density 
has seen a steady and ongoing decline for more than thirty years. The population density currently stands at around 8.51 inhabitants $/ \mathrm{km}^{2}$, and in the case of Almadén specifically, it is 22.16 inhabitants $/ \mathrm{km}^{2}$. The greater population density in Almadén is due to the fact that it is a centre for many basic services and has the highest overall population in the area, with 5312 registered inhabitants in 2019 [30]. The area's demographic changes follow a pattern of population loss with an interannual variation of $-2.73 \%$ with respect to 2018 , according to data from INE (Spain's National Electoral Registry).

Almadén lies within a district in the southwest of the Ciudad Real province, in between Spain's Meseta Central plateau and the Guadalquivir river valley. The territory is on the borders of three provinces in three autonomous communities: Ciudad Real (Castilla-La Mancha), Badajoz (Extremadura), and Córdoba (Andalucía).

The word Almadén has Arabic origin (al-ma'din), whose meaning is "the mine", and refers to the Arab occupation in the area. The Arabs settled around the mine and built the hins al-ma'din, the mine fort. After the conquest of Alfonso VII in 1151 the fort remained under Muslim influence, and in 1168 this territory became part of the heritage of the Order of Calatrava.

\subsubsection{Origin and Development of Mercury Mines}

The economic development of Almadén is associated with the local reserves of cinnabar, from which mercury is extracted. This metal is rare, but in Almadén, appears in extraordinary concentrations and these deposits have been mined for more than 2000 years. Although there are also deposits of lead and zinc, the most important reserves are those associated with the mercury extraction industry, most prominently those at Almadén, El Entredicho and La Vieja Concepción, and of secondary importance, those at Las Cuevas, Nuevo Entredicho and Nueva Concepción. The area around Almadén has the largest reserves of mercury in the world. Palero [31] puts a figure of 270,000 tonnes on the amount of cinnabar extracted from the Almadén mining region, a quantity that represents a third of global production. The magnitude of production on this site hints at the incredible changes to the landscape that must have taken place and how deeply the cultural landscape would have reflected that economic foundation and mining culture.

The interest in mercury throughout history places Almadén in a strategic position on multiple fronts. From the geological perspective, its cinnabar reserves are unique in the world with the highest levels of productivity. Of particular importance are the macrostructure known as the Almadén syncline, 25 by $10 \mathrm{~km}$ in extent, and the bodies known as roca frailesca (friar's rock).

A particular feature of the Almadén syncline are the outcrops of sedimentary rock dating from the Palaeozoic era, between the Early Ordovician and Late Devonian periods. This is where the principal orthoquartzite lithostratigraphic unit Criadero Quartzite is found, which hosts the largest concentrations of mineralised mercury. This is located most specifically at the San Pedro, San Francisco, and San Nicolás beds in Almadén, although it appears at other sites such as El Entredicho. The roca frailesca found within the syncline are explosive tuffs, of igneous origin, peculiar to the Almadén region.

From the historical viewpoint, Almadén has had a significant role due to the high demand for its mineral wealth. Both lead and argentiferous galena, found in the nearby Valle de Alcudia and Sierra Madrona, were already being extracted in the pre-Roman era. However, it was the exploitation of cinnabar, which the Romans used make the dye vermillion, that increased the mine's importance. After the Visigoths came the Moors and restarted mining activities from the 8th century to produce vermillion, and, in addition, mercury itself, a substance highly valued by alchemists and in medicine [32]. In the 13th century, the Almadén mines passed into the hands of the Order of Calatrava until the 16th century, when it became the property of the Crown. However, it was after the discovery of the Americas that the mines experienced their glory days due to the use of mercury amalgamation for gold and silver mining in the New World. Even so, it was only after the Spanish Civil War that the mines reached their maximum levels of production. 
The importance of mercury places Almadén on the path of several historical trade routes between several influential areas. These routes include the Roman Toledo-Córdoba route, the Camino Real (Royal Route) between Seville and Madrid that was in use from around 1775, and the Camino Real de La Plata (Royal Silver Route) [33] which passed through Seville's shipyards and thence, by river, to San Lúcar de Barrameda, from where fleets would depart for the New World. For many centuries, Almadén was obligated to Seville because this was where all mercury trade was directed, almost always destined to enable the silver industry of the Americas. The transport of mercury, commonly known as azogue, connected an extensive area and, from the 15th through to the 19th century, gave the region significant economic power.

The economic activity associated with mineral exploitation, over a time span of 2000 years, has left important archaeological remains from different eras and cultures, both in terms of architecture and technical artefacts. For example, there are the Arabic furnaces dating from the 8th century through to the baroque edifices of the Academy of Mines and the San Rafael Royal Hospital for Miners. Indeed, people speak of a "revolution in construction and architecture in the middle of the 19th century" [34].

The reduction in global demand for mercury and the appearance of new players in the mercury extraction market, such as China, Kyrgyzstan, and Algeria, contributed to Almaden's decreasing mercury production. However, the reasons for the complete shutdown in activity at Almadén lay in environmental concerns.

The decline in mercury mining began in the 1970s after international anti-mining protests on the part of various organisations and interest groups: the WHO (World Health Organisation), UNEP (United Nations Environmental Programme), Ecologistas en Acción (Ecologists in Action), Bureau Européen de l'Environnement (European Bureau for the Environment) and even the European Union, through its Community Strategy Concerning Mercury adopted in 2005. Restrictions on mercury extraction processes gave rise to counterprotests by mine workers in 1979 and 1984. The underground sit-ins staged by the miners constitute a revindication of mining culture and were the subject of a 2019 documentary (El Encierro), released to mark the fortieth anniversary of the first sit-in protest. The filming of this documentary has reanimated mining culture and renewed many old demands to increase the visibility of the Almadén district and to take more incisive action over the demise of its mining industry [35].

In 2019, the protests were re-enacted symbolically by the people of Almadén to highlight the problems that the region still faces. This district has been categorised as an area within "deserted Spain", and Plataforma Forzados was created in 2019 to enable local people to channel their demands [36]. The demonstrations reflect the disquiet surrounding the potential that Almadén's industrial heritage may have to re-energise the local economy. Amongst the demands of the population are, for instance, taking forward plans to re-industrialise, making industrial land available at low cost, the A-43 motorway route, connecting the district's towns by rail-links, and putting into operation a Strategic Plan for Industrial Tourism in Almadén. At the same time, they have requested that the Autonomous Administration make comparative improvements with respect to other sites declared as part of the World Heritage in Castille-La Mancha, the creation of a business advisory office, more access to funds from the European Liaison Entre Actions de Développement de 1'Economie Rurale (LEADER) project, handing over management to the Montesur Association, and improvements in the drinking water infrastructure.

All mining extraction was stopped in 2001, although industrial activity, exploiting the residual stockpile, continued until 2003. Euro Chlor, the largest association of the European Chlorine industry, agreed the sale of all Almadén's stockpiled mercury on condition that direct extraction be reduced. Although public administration has attempted strategies for local economic diversification, such as PRECA (Almadén District Economic Reconversion Plan 2007-2013) through which the state-owned company MAYASA S.A, part of SEPI (State Society for Industrial Participation), redirected extraction activities towards the production of red mercury oxide and basic mercury salts; consultation and contracting of geological 
works, these projects have not actually been successful. Currently, MAYASA focuses its efforts on the management of the Almadén Mining Park.

5.1.2. Results of the Transformation: The Process of Evaluating the Almadén Mines and Their Functionality as Tourist Attractions

Since 1998, the Local Action Group (LAG) for the Southern District has taken forward several projects for rural development within the framework of the Operational Programme for Rural Development PRODER 1 (1998-2002), PRODER 2 (2002-2007), LEADER (20072013) and currently, LEADER 2 Axis 19 of the Rural Development Programme in Castilla-La Mancha (2014-2020). Amongst the concerns surrounding the development of the Almadén district are the lack of job opportunities and low levels of investment in basic public services. Due to these problems, the region is a target of Spain's National Demographic Challenge [37].

Besides the actions taken within these rural development programmes, Almadén is starting a process of renovating its mining complex. This action is supported by the Ministry of Culture, and has the aim of renovating and enhancing the value of their mining heritage. One of the most important goals, and an emblem of industrial heritage, is the creation of the Almadén Mining Park. It involves the reuse of mining spaces for the purposes of culture and tourism. The refurbishment of the mines as the Almadén Mining Park, and their reuse as a sociocultural space, was enabled through the Almadén Mining Park Management Plan.

Industrial spaces, which have been somewhat invisible from the heritage perspective, are beginning to be re-evaluated with the appearance, in this new millennium, of new ways of looking at and interpreting heritage and land. In Spain, several factors have contributed to the comprehensive re-assessment of industrial heritage [38]: world recognition of Almadén's mining heritage as a World Heritage Cultural Landscape (2012); the European Landscape Convention (2008); regulated development to ensure conservation based on new conceptualisations of heritage; the Bierzo Charter for the Conservation of Mining Heritage (2008); the National Plan for Industrial Heritage (2002), and the ICOMOS International Charter on Cultural Tourism in 1999, which involves the democratisation of industrial heritage and a broadening of the term, heritage, to include territorial regions at the world level [36]. Within the academic field, concerns about heritage have a more territorial character and are ultimately based on precepts such as those laid out in the Manifesto for a New Territorial Culture (2006), which is promoted by Spain's College of Geographers and the Spanish Association of Geography (AGE).

Taking an integrated view of territorial heritage, it can be a way of enhancing a new set of resources as potential tourist attractions. In other words, it is one way in which mining installations can be re-purposed as new products for industrial tourism. The development of tourism in Almadén is related to giving a value to heritage through various legal protections and recognition of their significance [39]. Although it is one of the reference experiences in Spain, tourist activity in Almadén is moderate and is mostly linked to educational visits [40]. Figure 3 shows how visitor numbers have changed year by year since its opening, with the Mining Park receiving between 10,000 and 15,000 visitors annually.

In 1992, several industrial heritage sites were declared Cultural Interest Assets (BIC: Bienes de Interés Cultural), these included: the Historic Archive of the Almadén and Arrayanes Mines, the San Rafael Royal Hospital for Miners, and the Bustamante Furnace. In 2008, taking a wider approach, the Governing Council of the autonomous community of Castille-La Mancha declared that the entire mining complex at Almadén should be classed as a BIC, categorising it as a Historic Complex, with legal protection being extended in 2016 to include further fixed assets. Having previously presented a case for consideration as a UNESCO World Heritage Site, in 2012, Almadén and its mine were accepted onto the list of sites jointly with the Slovenian city of Idrija under the title of "Heritage of Mercury. Almadén and Idrija". For Almadén, this meant protection for a whole area including the following sites: Almadén-Old Town, Castillo Mining Buildings, Royal Forced Labour 
Gaol, San Rafael Royal Hospital for Miners, and the Bullring. The area covered is $49.66 \mathrm{Ha}$ with an additional buffer zone of 1117.25 Ha (Figure 4).

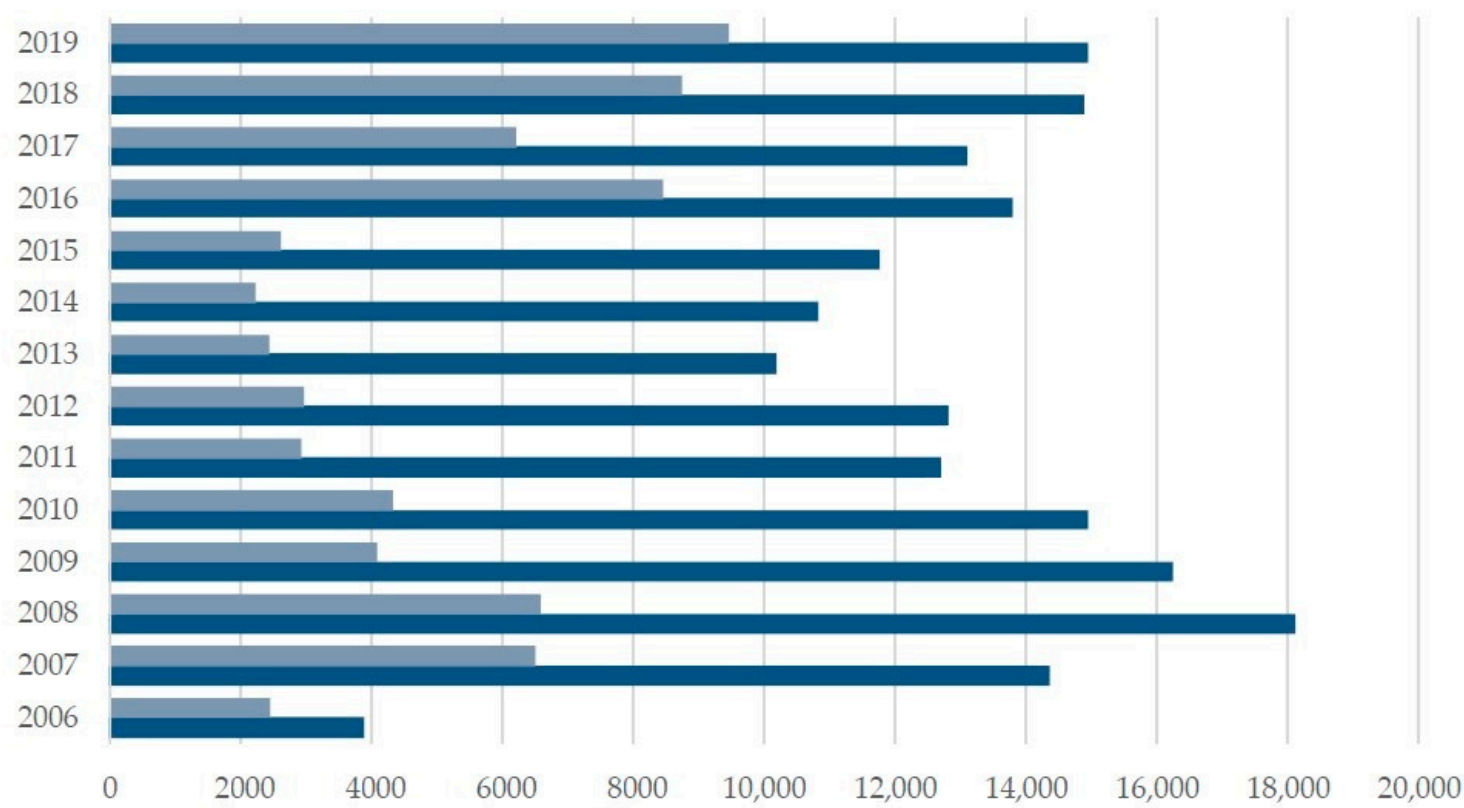

Figure 3. Number of visitors (source: adapted from [29]).

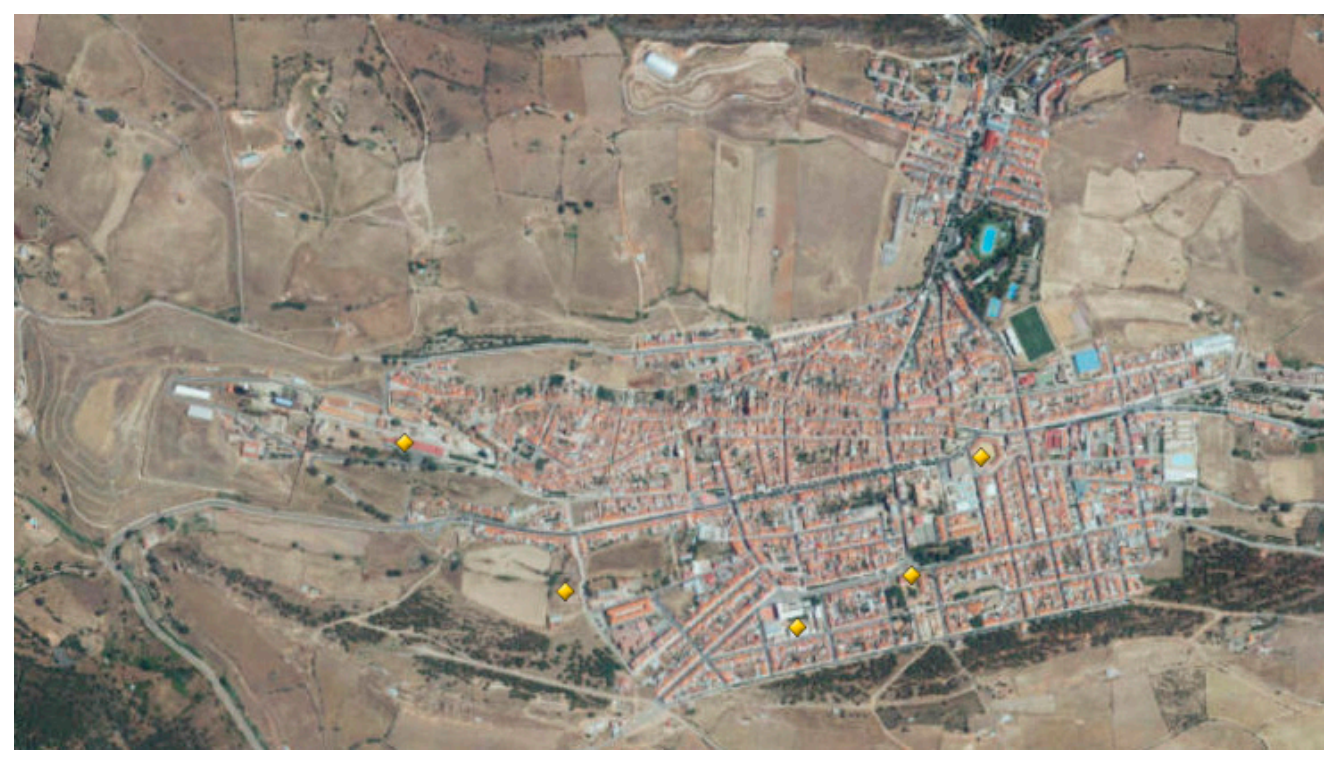

Figure 4. The different features around Almadén protected by the area's designation as a UNESCO "Heritage of Mercury" site. Source: https:/ / whc.unesco.org (accessed on 18 July 2020).

Since 2019, Almadén has been certified as part of one of the 38 Cultural Routes of the Council of Europe. Almadén is also an Anchor Point on the ERIH because it is considered of particular historical importance with regard to industrial heritage. This fact, apart from meaning the recognition of its heritage value, acts as an indicator to visitors, highlighting it as a tourist attraction of special interest and suitable for visiting.

Almadén's regeneration as industrial heritage has promoted the development of new tourism products. Within the framework of the European programmes for rural development, several local projects have been set up with the objective of defining Almadén's future. Industrial tourism was addressed as one of the types of tourism that could be 
encouraged [41]. Within this model, the Mining Park constitutes a strategic development zone, as reflected in the Strategic Plan for Industrial Tourism in Almadén and Surrounding Area (2015-2016).

The Almadén Mining Park project was conceived through a body known as MAYASA and developed with the help of the Almadén-Francisco Javier de Villegas Foundation as a museum-based enterprise in 1999. In 2002, in collaboration with the Spanish Institute for Historic Patrimony, the management plan for the Almadén Mining Park was drawn up. The aim of this was to "alleviate the decline due to the economic non-viability of mining activities and to show visitors about the mining and metallurgic processes associated with mercury production with tours of the interior of the mines" [42]. Quality System was the company responsible for developing this project between 2004 and 2007. The Mining Park proved to be a highly effective means of restoring Almadén's heritage and environment, and it has become something of a tourism nerve-centre.

Among other elements, the project encompassed a study of museums and museum design, studies of viability, finance, and economic management (including a communications plan), and was funded through European grants and with the collaboration of several other entities [43]. The mining park is a benchmark for the renovation and reuse of mining heritage, and as a result, apart from winning several regional prizes, it was a finalist in the sixth Regiostars Awards, organised by the European Union as an example of innovation, quality, and good practice.

A visit to the park includes a trip to the San Rafael Royal Hospital for Miners. Tours begin at the visitor's centre and continue to the old workshops, the winding towers at the San Aquilino and San Teodoro mine shafts, and the Mining Exhibition Centre. At the exhibition centre, visitors can access the underground part of the tour and see the interior of the mine. Visitors end the subterranean section of the tour by taking a wagon train, renovated for tourists, back to the surface where it continues with a visit to the Alúdeles furnaces, which date from the 17th century, the Carlos IV and Carros Gates and paved road and the brick furnaces, continuing to the Mercury Museum, and finishing at its starting point, the visitor's centre.

According to data provided by the park, concerning their visitor satisfaction questionnaire which has been in use since 2013, out of a total of 1075 responses, $59.44 \%$ evaluated their experience as very good, $12.47 \%$ as good, and $28.09 \%$ as acceptable. The interior of the mine is rated as very good by $42.24 \%$ followed by the visitor's centre rated as very good by $24.93 \%$. The exhibits at the Mercury Museum are rated as very good by $53.91 \%$ of visitors. In general terms, visits to the park are evaluated positively, especially the visitor's centre, which has adapted well to the needs of its visitors. These data agree with results from other studies [44] which, as can be seen in Figure 5, show the park's attractions as being the most highly evaluated resources, and amongst these the visitor's centre stands out. On the scale from 0 to 5 , where 0 is the lowest valuation and 5 the best valuation of the attractions of Almadén, in the upper graph it is observed that the vertices of the lines furthest from the inside and, therefore, the best valued, are the Mining Hospital, Mining Park, and Bullring, rated better than the Palaces, Parish church or Archeological Museum, which approximate values between 0 and 1. In the lower graph, there is greater equity. Only the workshops obtain a lower score, close to 1 .

In conclusion, we can extract that after the preparation of the Special Protection Plan and Catalogue of the Almadén Historical Mining Complex prepared by the City Council and the Heritage and Archaeology Service of the General Directorate of Culture as instruments for the protection of heritage, as a consequence of the declared World Heritage by UNESCO in 2012, visits did not increase in the following years, but it was from 2015 when there was a notable increase. Despite the recognition of the heritage value of the mines, the population has mobilized against the closure of the mines after 2000, in favour of local employment and defending the mining tradition and culture, apart from the environmental debate. The consequence of the closure of the mines in 2011 led to a decline in economic activity and population in the region. This rejection is on the fringes of 
the debate surrounding the environmental contamination of mercury and in the absence of expectations, at least in the short term.

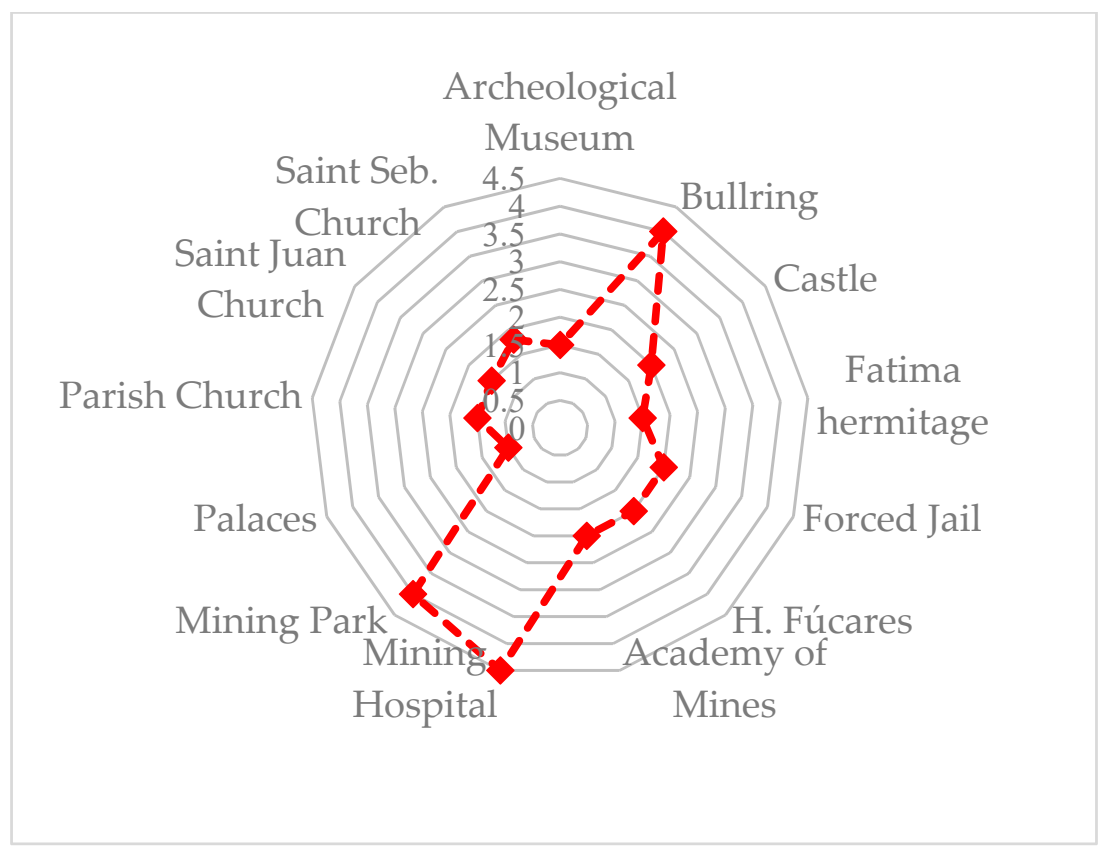

(a)

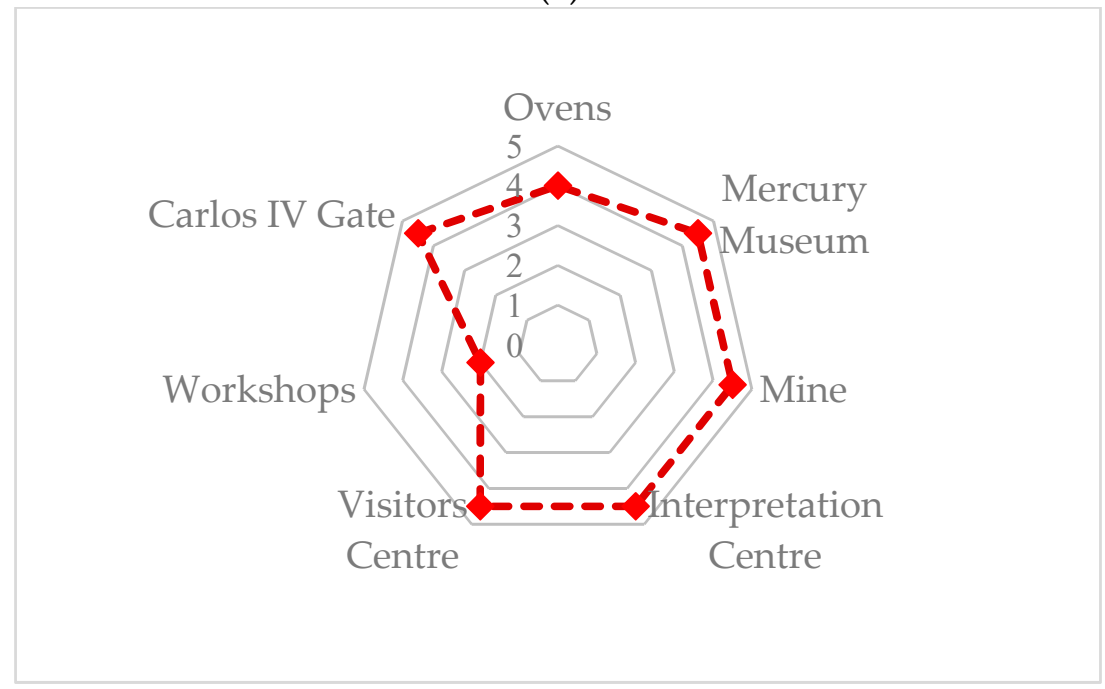

(b)

Figure 5. Evaluation of the principal tourism attractions in Almadén (a) and in the Mining Park (b) (source: [29]).

Regarding the management of the site, there are important differences with respect to the entrance fees of Sabero. In the case of Almadén, its price increased considerably after being included in the list of World Heritage, only offering discounts for school groups, which are the dominant groups among the visitor profile.

The individual visit costs EUR 14 for adults over 15, EUR 12 for the over-65s, and EUR 11 for children. Group visits are made with a minimum of 12 people, preferably from Wednesday to Friday. The group visit costs EUR 12 for general admission and EUR 10 for the over-65s and students. The entrance fee includes, in addition to the mine, a visit to the San Rafael Mining Hospital if both visits are made on the same day or the day after. The visit to the mine lasts approximately $2.5 \mathrm{~h}$ and two visiting shifts are guaranteed (morning and early afternoon). 


\subsection{Sabero}

The municipality of Sabero is in the northeast of the Iberian Peninsula, in the mountainous region that separates the provinces of León, Asturias and Palencia, in the valley of the river Esla, close the Picos de Europa National Park. It is part of ADSACIER (Association for Development in Sabero, Cistierna and La Ercina), a body that brings together these three municipalities with the aim of promoting employment generation projects through the management of public aid and private investment. It is also part of the Local Action Group of Montaña de Riaño, an association initially formed of 21 municipalities that has, since 1996, been charged with managing European rural development funds. At the time, this group of 21 Montaña de Riaño municipalities had a joint population of 19,622 inhabitants [45]. By 2019, this figure had dropped to 12,606 inhabitants, with a population density of 6 inhabitants $/ \mathrm{km}^{2}$ [30].

\subsubsection{History, Development, and Crisis in the Mining and Industrial Sectors}

The district of Sabero is rich in mineral reserves, and due to the unique quality of its coal, these resources have been exploited over the decades. At the end of the Hercynic orogeny, several different coal basins developed in the Cantabrian mountain range along its principal structural axes [46]. The extent of the Sabero basin is small- $14 \mathrm{~km}$ long by $2.6 \mathrm{~km}$ across at its widest point-and follows the east-west axis of the Sabero-Gordón fracture zone. In 1841, the anthracite coal field in the Sabero valley became the first to be mined in the province of León [47]. The properties of its coal, specifically the high sulphur and oil content, generating a short flame when burned, made it particularly good for coke production [48].

These conditions, combined with the existence of iron reserves in the same district (La Imponderable and La Salud mines) saw Sabero become the first Spanish iron foundry to use mineral coal; in 1847, long before other industrial centres in Asturias, the Basque Country or Catalonia. This was in large part due to the impetus of a group of engineers and liberal capitalists, including such names as Miguel Iglesias Botías, Casiano de Prado, Santiago Alonso Cordero, Ramón de la Sagra and the French engineer Philippe Paret [49]. Sabero's advantage was, however, only maintained for 16 years (1847 to 1862) after which use of its blast furnaces ceased. The severe difficulties of production and transport meant that Sabero's iron industry was as short-lived as it was revolutionary. During this time, the French engineer Paret, contracted by the Palentino-Leonesa Mining Society, erected the complex of buildings now emblematic of Spanish industrial heritage. Amongst these was a management building, workers quarters, homes for teachers, warehouses, blast furnaces, and the lamination hall, also known as the San Blas ironworks (Figure 6), a neogothic building modelled on the steelworks at Ales, France. The most advanced machinery of the time was imported from England, and after arrival at the port of Gijón, was transported to Sabero on ox carts. The first blast furnace began work in 1847, shortly before those at Trubia and Mieres in Asturias went into production [48].

The first stone of the building that was to become the Sabero ironworks was laid on 14 March 1846. The novelty of these facilities with respect to existing works in Malaga was that while those works used charcoal, Sabero pioneered the use of mineral coal (coke). This new process enabled increased yields, to the extent that, at times of maximum production, Sabero's furnaces could produce more than nine tonnes of iron per day [50].

The Sabero ironworks had a short history, plagued with problems. While the PalentinoLeonesa Mining Society was proactive in its attempts to raise capital and improve the installation (a second blast furnace began work on 21 January 1860), these efforts were counteracted by difficulties of transporting their product to market in addition to direct competition from other coal mines (Orbó in Palencia) and ironworks in more favourable locations. The major markets for Sabero's cast and forged iron were León, Palencia, Valladolid, and Madrid. From Sabero, iron would be transported in ox carts to Sahagún over a distance of $50 \mathrm{~km}$ on unmetalled tracks at a cost of 4 reales per hundredweight and from there, a further $350 \mathrm{~km}$ to Madrid at a cost of 8.7 reales per hundredweight [48]. 
Apart from the obvious transport difficulties and competition from other businesses, the Palentino-Leonesa Mining Society was faced with numerous surcharges and penalty tariffs which, due to the impossibility of obtaining any new injections of capital, placed the business into a deep financial crisis and the blast furnaces stopped work in 1862. With societal change and the lifting of certain embargoes, the Sabero works eked out an existence from sales of coal extracted from its mines for three more decades, before the business was finally liquidated in 1892. The mining rights were bought by the Basque investment capital company, Hulleras de Sabero and Anexas S.A., initiating a new chapter in the history of the town. Henceforth, the focus became solely the extraction of coal and its transport to steelworks in the Basque Country via a new railway, finished in 1894, between La Robla (León) and Valmaseda (Bilbao).

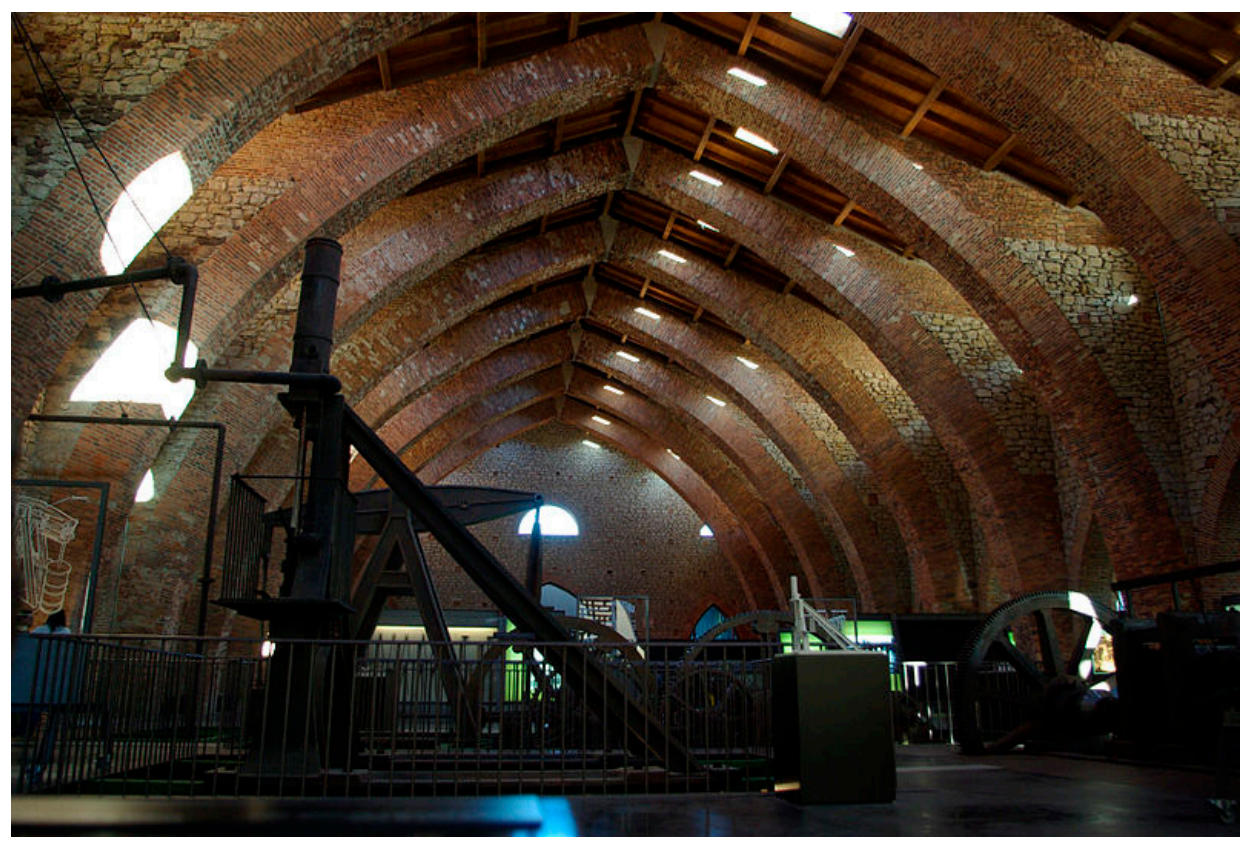

Figure 6. Interior of the lamination hall at the San Blas Ironworks. @ David Pérez (DPC), Wikimedia Commons, License cc-by-sa-4.0.

The Hulleras company extracted coal from mines in the Sabero basin (including Quemaduras, Herrera I in Sotillos, and Herrera II in Olleros), and transported the coal along its own railway track to the industrial complex it built in 1899 in Vegamediana on the banks of the river Esla. Here, the coke was washed and prepared before being transported on, again using Hulleras' own rail link, to the terminus at Cistierna where the coal wagons would be coupled to locomotives running on the Robla-Valmaseda line. For many decades, the Hulleras mine train transported millions of tonnes of coal from the coalfields of León and Palencia to fuel the Basque steel industry. These years saw the greatest population growth in the area, with five localities being taken out of the control of the Cistierna town council in 1927 to form the new council area of Sabero, which, in the 1930 census, recorded 2580 inhabitants. In 1960, the population reached its maximum, with 5016 inhabitants, and from that point economic slow-down in the mining basin meant that the population declined rapidly_today reaching little more than 1000 people (1140 inhabitants in 2019). In 2019, Sabero, the centre of Hulleras' operations with a workforce that, at one point, reached up to 2000, had only 533 inhabitants [30].

These figures expose the magnitude of the disaster, of the crisis that engulfed this region of the province of León, and other Spanish mining districts. In this particular case, decline began in the 1960s, when the era of self-sufficiency imposed by the Francoist regime began to be relaxed and the country began to import large quantities of oil, meaning 
that local coal lost its traditional markets. Despite the opening of several power stations (including one located $30 \mathrm{~km}$ from Sabero), which from then on absorbed the majority of regional coal production, a large number of mining companies ceased trading towards the end of the 1960s. According to the census taken in 1970, the municipality of Sabero, which, as mentioned, had a population of 5016 inhabitants in 1960, had only 3413 inhabitants. This amounts to a population reduction of $32 \%$. The end of this decade saw the closure of the majority of the small mining businesses that had once thrived in the Sabero valley to leave essentially only one survivor: Hulleras, although with a much-reduced workforce [48].

Throughout the following decade, the 1980s, Spain began a process of industrial restructuring. A large number of companies from various branches of industry were compelled to close due to their inability to compete on the international market, adjust to European regulations and sustain wage increases, while working in what were, ultimately, antiquated facilities, making outdated products. These were years of industrial unrest in shipbuilding yards, in the big city industrial belts, and also in mining districts, where pressure from miners was rewarded with direct aid and extraction subsidies that significantly postponed their closure. Mining communities, such as that of Sabero, resisted the closure of the principal, indeed practically, the only source of local employment, regardless of international treaties aimed at forcing the closure of this highly contaminating industry and associated power stations.

Since the 1990s, there has been an incentivised and progressive shutting down of all coal mining activity. This has involved retraining programmes and economic stimulus packages for affected areas; measures that were repeatedly extended due to public pressure until, on 1 January 2019, the few mines that remained open-26 compared to 270 registered in 1988-were finally closed for good.

In 1990, Hulleras presented a plan for the closure of the mine in Sabero, an act that provoked protests from the workers at the beginning of 1991. The owners alleged that the complex was completely economically unviable and offered to hand on all installations and machinery should another business come up with an alternative proposal to maintain operations. After a long process of negotiation, Hulleras stopped all coal production on 31 December 1991. However, it did subcontract the operations at the open cast mines, Sabero 6 and 8, near to Sotillos, until 1993. From 1992, several economic redevelopment plans were put in place, subsidised by the Sabero Zone Reindustrialisation Board, in relation to cattle ranching, industry, or advanced services. However, these have not been successful. Finally, the San Blas ironworks were promoted as a cultural package to attract tourism as the last opportunity to this valley, a project backed by the Sabero Mining Museum Friends Association [51].

The Friends Association was the real impetus behind the industrial heritage museum initiative. Indeed, the project had precedents: in 1973, the Sabero Town Council had set up the Mining Museum in the municipal House of Culture which was remodelled in 1993; and in 1989 it had made a petition to the Castilla-León Regional Council to recognise the San Blas ironworks as an official monument with the status of BIC. The Friends Association requested that Hulleras transfer ownership of its installations to the municipality for cultural purposes. The transfer went ahead in May 1993, and in 1994 a grant was requested from the León Provincial Government to take the project forward. A year later, in August 1995, the regional government announced that the Autonomous Administration would take charge of creating a mining museum in Sabero.

The process of restoration and museumization of the ironworks was slow and beset by problems. There were numerous arguments between experts and local politicians and successive changes to the plans involving modifications to the original project, in addition to legal issues which paralysed the execution of the project. The most significant of these issues concerned the archaeological excavations, which brought to light important findings about the site's iron-working history, and which had barely been considered in the museum project. Experts and politicians needed to decide, therefore, whether the museum should be confined to an exploration of the district's mining history alone or whether to revive the 
original idea of including the iron-working history too in order to provide a unique and wholly memorable tourist experience. Fortunately, the second option won out.

5.2.2. Results of the Transformation: The Iron-Working and Mining Museum in Castilla and Leon

The Iron-working and Mining Museum (MSM; Museo de la Siderurgia y la Minería) was opened officially on 3 July 2008, and since then it has become the cultural centre for the district, hosting numerous activities to fill the region's cultural calendar. The MSM has a permanent exhibition which, for the most part, deals with Sabero's iron-working history, and to a lesser extent with its coal mining activities. In theory, a second phase in the museumization of this old industrial complex will allow the transfer of mining artefacts, including many items currently stored away in other locations, to a second exhibition building. Thus, there will eventually be two separate spaces, one dedicated to iron-working and another to mining. It must be said, however, that the second phase has yet to begin.

One of the side galleries off the central nave of the museum's neogothic building is used to host temporary exhibitions on themes related to industrial production and mining. Outside is a reconstruction of the Sabero pharmacy, which served the ironworks since it opened, and the tavern.

Lastly, throughout the year, many different cultural activities are held either within the museum's main exhibition space, in the landscaped surrounds or in the new annexes. These so-called parallel activities include concerts; workshops for children and youngsters; book readings; courses; conferences; screening documentary films; open air cinema shows; and live performances, amongst many others.

As shown in Figure 7, since the museum opened the trend in visitor numbers has been irregular. Overall, it has recorded more than 250,000 visits between 2008 and 2019, with a peak in 2018 when visitor numbers exceeded 41,000, which contrasts with a low point in 2012 when barely 20,000 visitors were recorded. Of the four regional museums in Castilla and León (the other three being the Museum of Human Evolution, Burgos; the Contemporary Art Museum, León; and the Ethnographic Museum, Zamora), the MSM has received the least number of visitors. However, it must be said that the other three museums are all sited in provincial capitals with sizeable populations in contrast to Sabero, which had only 533 inhabitants in 2019.

If we look at the details of visitor surveys from the last four years (Figure 8), the museum's importance as a cultural dynamo becomes apparent with visitor numbers being equally distributed between its permanent exhibition, temporary exhibitions, and parallel activities. Now, it is true that a visitor entering the museum complex may well visit both the permanent exhibition and any temporary exhibits, because they are in the same building. However, it is less likely that this visitor will, on the same day, also be able to take part in one of the parallel activities, some of which take place outside the museum's normal opening hours. In fact, there are some months in which the number of people attending these parallel cultural activities equals that attending the exhibitions. Whatever the case, it is certainly true that visitor numbers calculated according to the number of entrance tickets sold is not a true representation of attendance at the various attractions. For example, according to MSM statistics, in January 2016, 643 entrance tickets were sold for the main exhibition. The same number of people, 643 , visited the temporary exhibition, and 688 participated in parallel activities, the majority of which took place within the opening hours of the main exhibition halls. Thus, the total number of visitors counted in the museum's statistics for that month is 1974, although it is possible that the real number is considerably lower. 


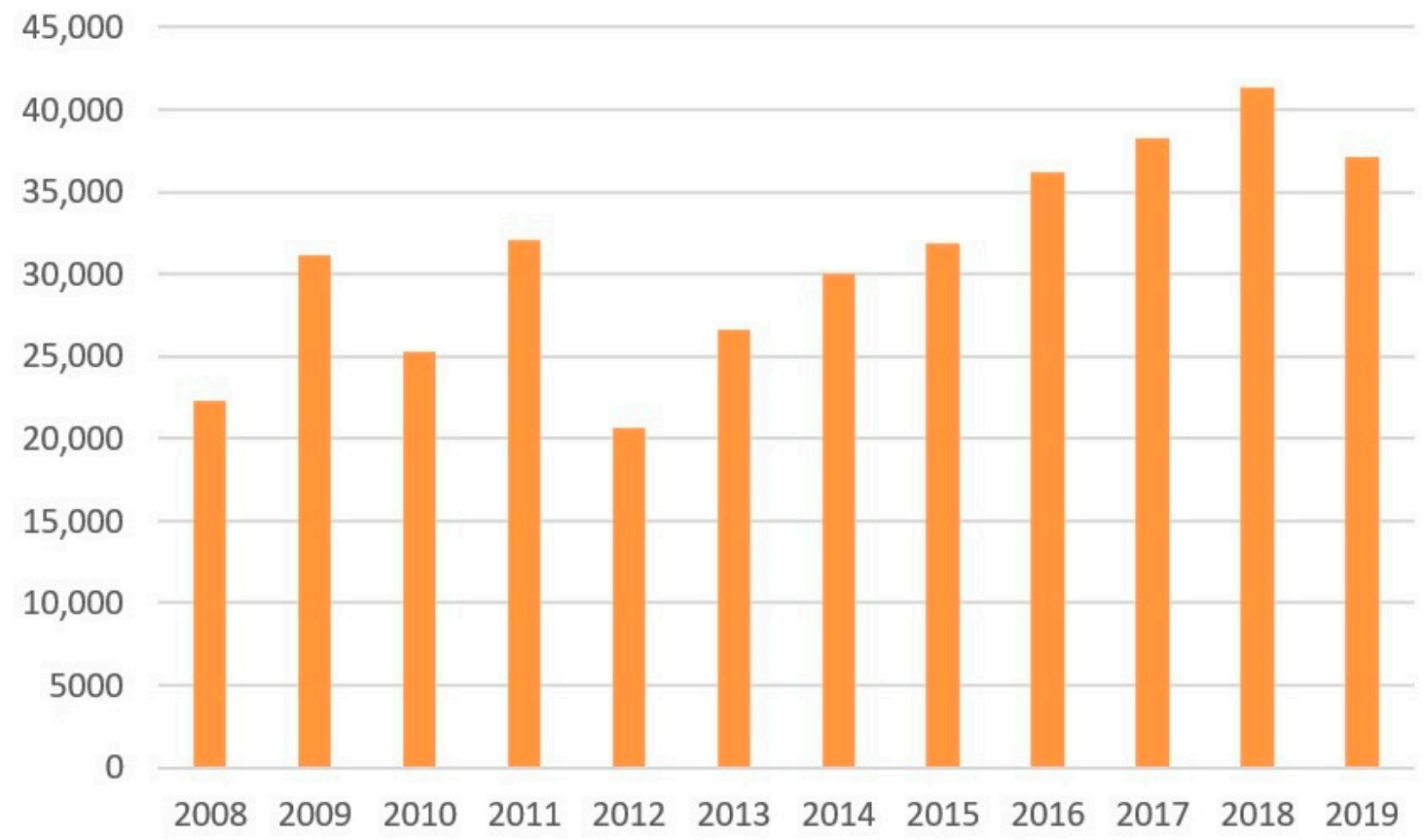

Figure 7. Visitors to the Iron-working and Mining Museum (MSM) (source: Junta de Castilla y León).

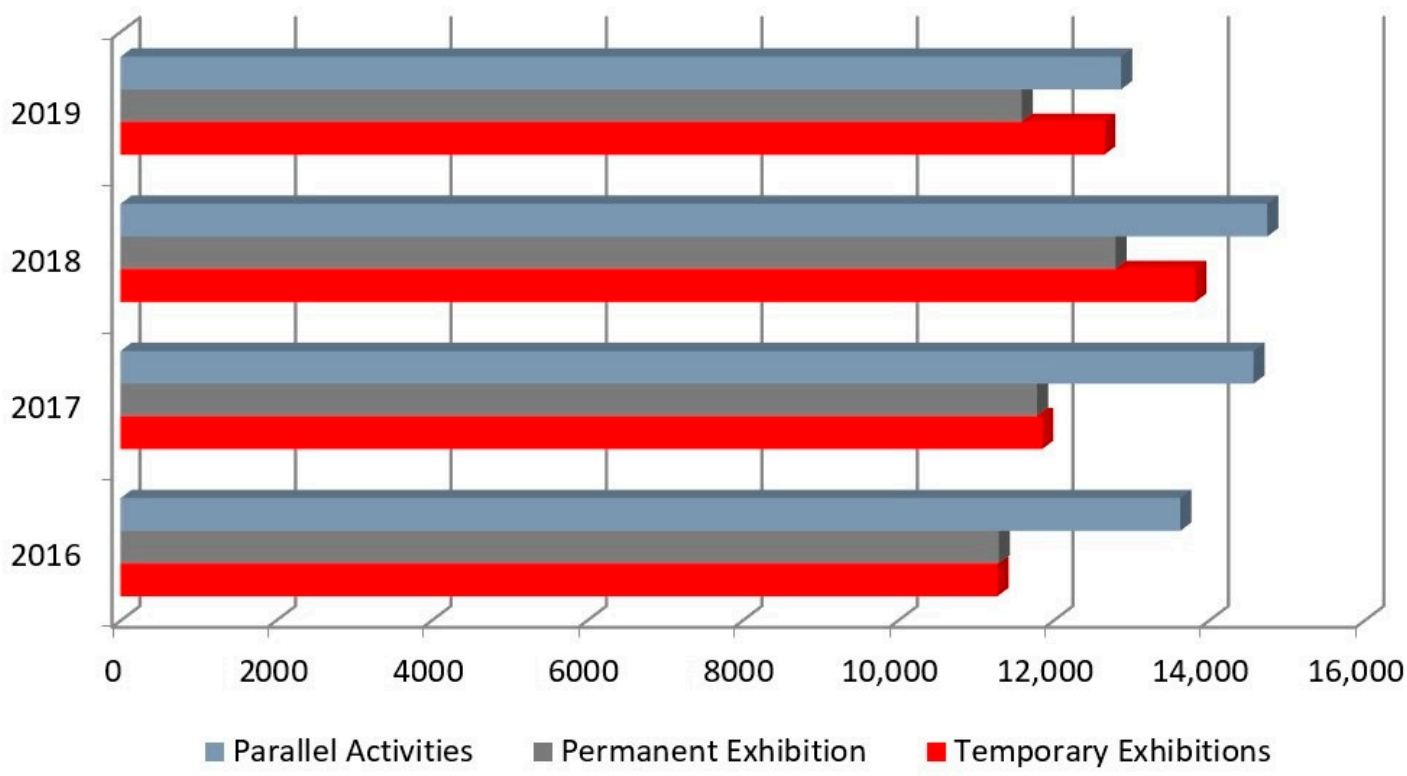

Figure 8. Detailed breakdown of visits to MSM attractions between 2016 and 2019 (source: MSM).

As Figure 8 demonstrates, in the last four years, the parallel cultural activities have attracted the most visitors, followed, at some distance, by the temporary exhibitions. Visits to the permanent exhibition, which might be expected to be the principal draw, show that it is the least popular attraction of the three.

Figure 9 helps explain the structure of visits to the MSM with greater clarity. What we see is a month-by-month break-down of visitor numbers recorded in the 2017 and 2019 surveys. As can be seen in the figure, the lines representing visitor numbers to the permanent and temporary exhibitions follow trajectories that are almost parallel, and indeed, superimposed. There are very few fluctuations except for two periods where visitor numbers increase over the summer and during the Easter holidays, and where they dip over the winter. In contrast, the line showing attendance at parallel activities shows 
far more variation, reaching its highest points during the summer months (when there are internationally recognised musical concerts) and in December (when there are festivities in honour of Santa Bárbara, including concerts, film screenings, and workshops).

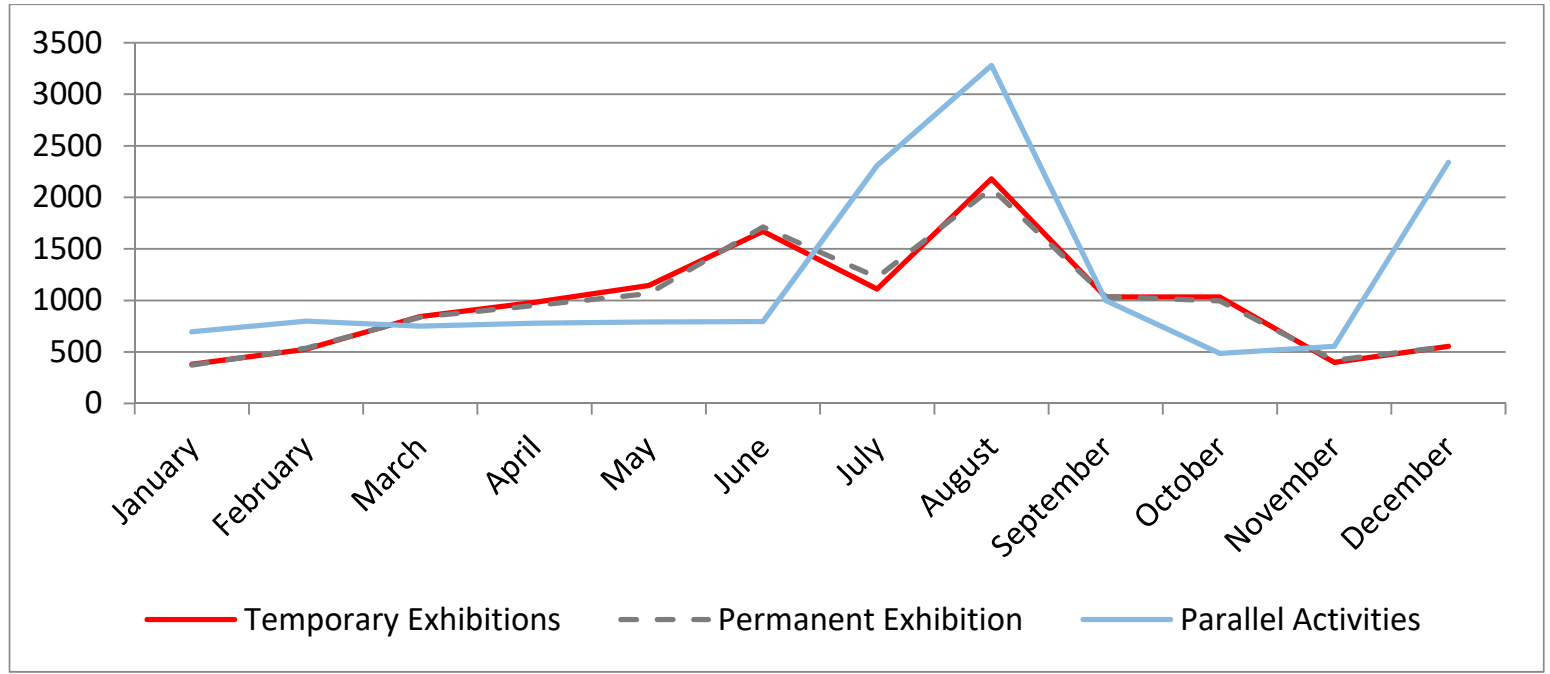

(a)

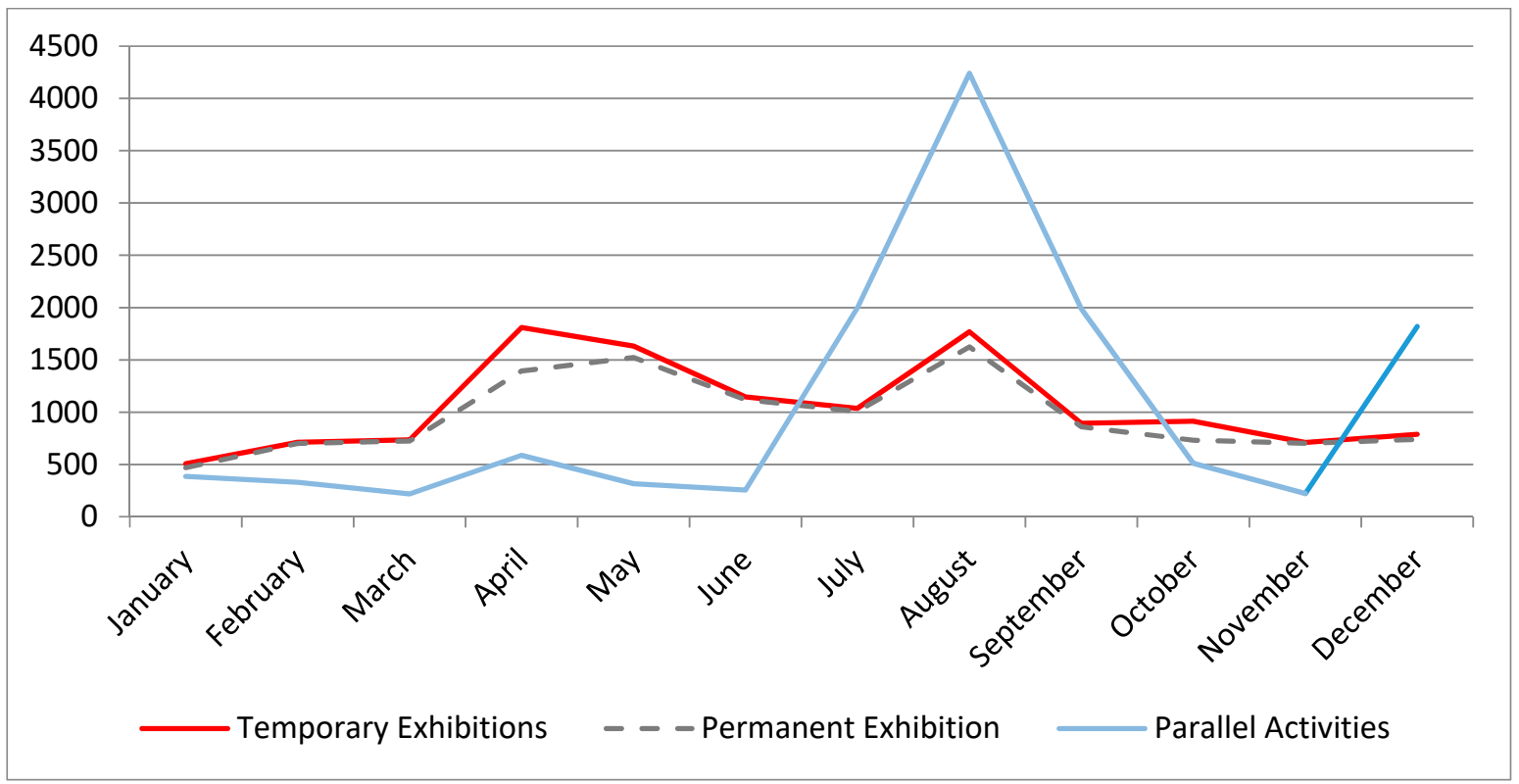

(b)

Figure 9. Month-by-month number of visitors to MSM in 2017 (a) and 2019 (b) (source: MSM).

Visitor numbers are a key performance indicator for the MSM, especially in terms of justifying the funding it has received from the Castilla and León Regional Government to restore the ironworks, build the controversial annexes, and indeed, maintain a set of attractions that barely generate any income. In 2006, the investment required to create the MSM's basic infrastructure was estimated to be in the order of EUR 11 million, although later this was adjusted upwards to around EUR 30 million. However, the cost of entrance fees is symbolic and often free, with the aim of increasing visits, despite the fact that since 2012, a regional regulation was put in place obliging all museums in Castilla and León to charge admission fees. At the MSM, entrance to the temporary exhibitions, housed in the side galleries of the building's main nave, is free. Admission to the permanent exhibition is EUR 2, with a concessionary entry fee of EUR 1 for children, students and large families. 
Free entry is granted to persons under 8 or over 65, to members of the MSM's Friends Association, and additionally, to teachers and journalists. Of the 11,592 admissions to the permanent exhibition in 2019, $7240(62.4 \%)$ were free entrances, $2930(25.2 \%)$ were concessions, and only $1422(12.2 \%)$ were at full price. These figures are not dissimilar to those seen in other years, according to the MSM's own statistics.

The Siglo Foundation is a public body set up under the auspices of the Autonomous Administration of Castilla and León and charged with administrating the region's museums, including the MSM. According to a report by the auditing committee of the autonomous community of Castilla and León, which inspected the Siglo Foundation accounts for 2016 and 2017, the MSM uses both estimated and real visitor numbers for its exhibitions, workshops and other activities as its principal performance indicators. In this way, in 2016 the museum had a figure of 31,000 for the estimated number of visitors, and that of 36,211 for the real number of visitors; in 2017 the estimated number of visitors was 37,000 and the real number was 38,189. The report also includes details of the museum's income, showing that in 2016 they reached EUR 26,163, a value that rose to EUR 34,463 in 2017. Nevertheless, the museum's running costs are far greater than this income and in 2016, the Fundación Siglo assigned funds to the MSM of EUR 525,000, and in 2017 funds of EUR 522,000.

\section{Results and Discussion}

In 2018 and 2019, in cooperation with the Regionalverband Ruhr, the organisation in charge of the ERIH conducted a barometer, or survey, of industrial heritage through a series of questions directed at the museums and recreational parks that form part the network. In 2019, the questionnaire was sent to 325 tourism operators from which they received 113 replies from 16 different countries. The questionnaires and data can all be found on the ERIH website (https:/ / www.erih.net/projects/erih-industrial-heritage-barometer/). A brief analysis of the results allows us to contextualise our two case studies, Almadén and Sabero, within the framework of industrial tourism in Europe.

According to the data uncovered by the barometer, 7 out of every 10 sites are in public ownership, managed by government or through foundations, while only $27 \%$ are in private hands. This has repercussions for the economic sustainability of these sites, since in 2019, one in three covered less than $20 \%$ of their operating costs through their income. Nor are these sites major sources of employment. The figures suggest that $60 \%$ of sites have fewer than 10 employees, while $40 \%$ have fewer than 5 . Moreover, issues relating to employment and finance, are, in fact, the major concerns outlined by the sites surveyed.

For the most part, the sites surveyed are open throughout the year $(97 \%)$, and the majority of their visitors are school groups $(90 \%)$, followed by families and the over$50 \mathrm{~s}$. Although there was a great deal of optimism for the future from respondents to the questionnaire with respect to potential visitor numbers, what is apparent from Figure 10 is that there is a great deal of difference between those sites that have high visitor numberswhich possibly comprise the rare $16 \%$ that cover more than $80 \%$ of operating costs from their entrance fees-and those museums and eco-parks that see less than 10,000 visitors each year ( $23 \%$ of all the sites surveyed).

The 2018 barometer obtained responses from 80 tourism operators in 12 countries, amongst which two were in Spain (2.5\%), compared to 59 in Germany (73.7\%). The 2019 barometer obtained responses from 113 tourism operators in 16 countries, where 18 were in Spain (16\%), compared to 65 in Germany (57.5\%). In this way, sites are more widely dispersed and include more peripheral locations in the 2019 barometer compared to that conducted in 2018. This small detail is reflected in a reduction in the mean number of recorded visitors overall: in 2018, $29 \%$ of sites surveyed said that they had received more than 100,000 visitors; while in 2019, only $21 \%$ said that they had seen this number. 


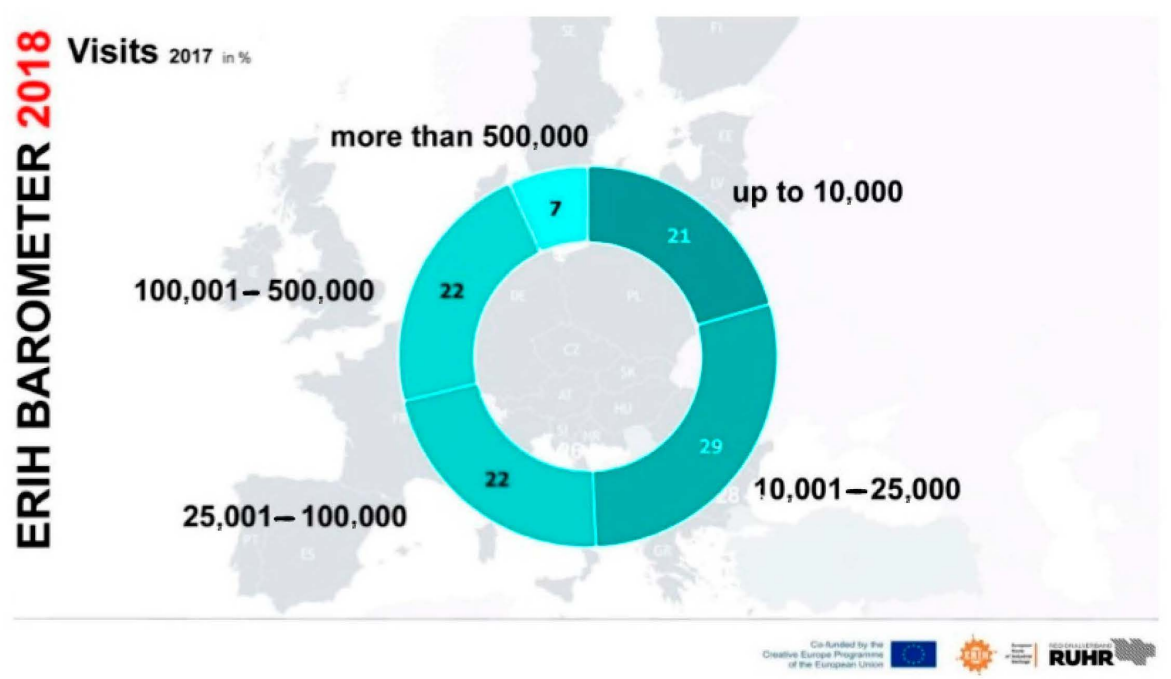

(a)

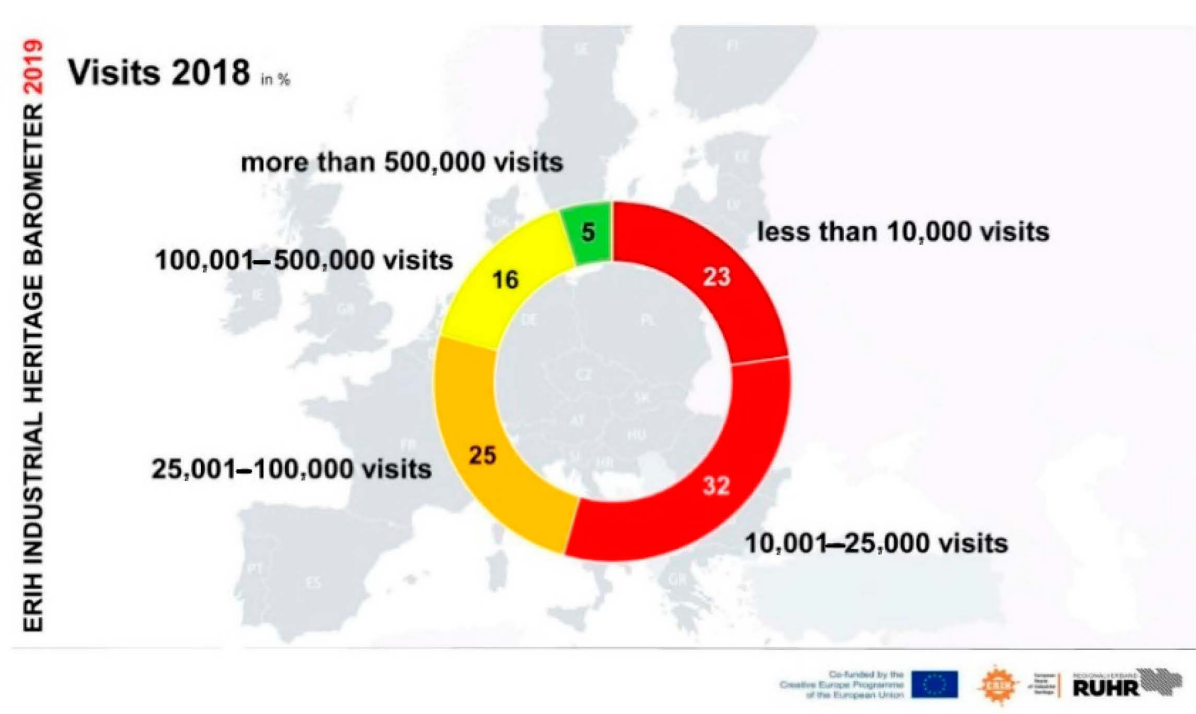

(b)

Figure 10. Number of visits to industrial tourist attractions according to the 2018 (a) and 2019 (b) ERIH barometers (source: www.erih.net).

Finally, the barometer also provided information about the origin of visitors, showing that $60 \%$ were regional, $30 \%$ national, and the remaining $10 \%$ were international tourists. These figures were unchanged between the two years surveyed.

Comparing these data with those from Almadén and Sabero, and considering those questions raised in the previous sections of this report, there are several points to discuss:

- Almadén and Sabero are both categorised as Anchor Points; however, according to their operational structure, they represent the smaller types of tourist attraction. In both cases, the workforce is fewer than 10 employees, and "real" visitor numbers are less than 15,000 per year.

- Almadén and Sabero both depend more heavily on public finance than other European industrial heritage attractions. In Almadén, $92 \%$ of operating costs are met by public funds. In Sabero, the figure is $95 \%$ due to the discrepancy between the site's income and funds allocated by the regional administration. 
- Where visitors come from also reflects their low impact index. More than $50 \%$ of visitors to Sabero were from the province of León itself, and in the case of Almadén, $40 \%$ were from Ciudad Real. For both sites, the number of international visitors was less than $1 \%$.

- Schools are an important target audience for both sites. Sabero organises numerous teaching activities to enrich visits and there is a programme of events directed at children. Almadén, meanwhile, has set itself up as the prime visitor site for all educational centres in Castilla-La Mancha, and states that educational visits are the principal motivation of $88 \%$ of all visits to its site.

- Both Almadén and Sabero are under constant pressure to increase visitor numbers. In Sabero, this metric is used as the only valid indicator of the site's success or failure, according to the public audits carried out. When speaking to the media, those in charge of these sites always give highest priority to visitor numbers, rather than mentioning other issues such as environmental regeneration; the parallel tourism infrastructure brought into being as a consequence of industrial tourism; employment generation, both direct and indirect; or the promotion of the image of local areas, and improvement to the quality of life of local people. It seems that the only important thing is to count (and recount) how many visitors have come to their museums.

- In both Sabero and Almadén, according to the opinions of the local society published in the media, and in demonstrations on the streets, the population has moved from an initial feeling of joy over investments and international awards to a general apathy, due to the low impact of industrial heritage tourism on the local economy. Former mine workers do not identify with the proposals for cultural transformation imposed by the public administration.

- The project that began with the creation of Ruhr's Industrial Heritage Trail in Germany had environmental renewal as one of its central aims, as well as cultural development and social rehabilitation. It was initially about the recovery of polluted rivers; the environmental clean-up of mines and spoil heaps; and regenerating landscapes. It was an effort to regenerate the land so that it could, once again, be the site of new development. In our two case studies, this initial lever does not seem to have been put in place.

- Furthermore, following from the definition of sustainability with regards to industrial tourism given by Myriam Jansen-Verbeke [20], the needs of tourists need to be balanced against those of the regions visited, to protect the local heritage while also providing opportunities for future development based on innovation and progress. This is exactly what has happened in the case of Ruhr's Industrial Heritage Trail, where, after years of decline, the region has found new energy and economic productivity. In contrast, while Almadén and Sabero provide protection for the region's industrial heritage there is no trace of any activities promoting progress and innovation in these areas that have suffered both population decline and weak economic activity over many decades.

\section{Conclusions}

This article began by referring to the ethical and social necessity of applying the criteria of sustainability to everything around us. That which is sustainable should be promoted and celebrated, while anything unsustainable should be disposed of forthwith or transformed into something that is sustainable as quickly as possible. The aim of this article, as laid out on its first pages, was to analyse the sustainability of industrial heritage tourism in isolated locations far from centres of economic development in Europe. The hope was to draw conclusions about whether this form of tourism, where visits are motivated mainly by interest in heritage related to the working culture of a particular place, was sustainable in locations that are peripheral to economic growth.

The theoretical framework of this study is linked to two concepts: sustainability and territorial resilience. Sustainability must be supported by three pillars: society, economics, 
and the environment; while the territorial resilience of the ex-industrial spaces studied must be assessed in terms of their capacity to recover from their crises and regenerate, thus reaching a new state of equilibrium.

As has been explained in this article, the development of industrial tourism in Europe was set in motion after the closure of numerous industrial complexes during the economic crisis of the 1970s. After several decades of disuse, these ex-industrial sites were then successfully rehabilitated as centres for cultural and recreational activities. This positive dynamic can be explained by several factors on both the supply and the demand side of the equation. Another consideration that needs to be taken into account here is that a prime motivation in those European countries, where this kind of thematic-recreational park has been pioneered, was the environmental, social, and cultural recovery of these densely populated areas where the generation of new employment and new economic activity can be planned for the short and long term. Furthermore, ex-industrial areas contain an abundance of assets that, with the "intervention" of industrial heritage tourism, can be transformed into valuable resources for tourism. These areas often lack any other features that might attract tourists or other recreational visitors, and as a result, without the kind of industrial heritage tourism described, they would otherwise be net losers of tourists to other regions. This is precisely the case exemplified by the Cultural Heritage Trail connecting numerous German cities in the Ruhr Valley.

The key idea of the ERIH is to expand industrial heritage tourism to other locations and to create a network of operators that would showcase Europe's industrial past to potential tourists. Within this network of 2000 sites, certain Anchor Points are highlighted as reference points in European industrial history.

In our two case studies, we looked at the development of the ex-industrial sites of Almadén and Sabero, as centres for industrial heritage tourism. The first of these constitutes an outstanding example of the regeneration and renovation of an industrial complex as a tourist attraction. Its excellence has been recognised through several awards and by its inclusion on the UNESCO list of World Heritage sites. The process of enhancing heritage and its reuse for tourism and culture has given rise to the creation of other tourist-centred facilities; however, the fabric of this new productive sector is still weak, as shown by how the local population revived their historic grievances on the 40th anniversary of the first sit-in protest by Almadén's miners. In the case of Sabero, the museumization of the old San Blas ironworks has been the source of ongoing disputes between the local population and regional government, with too many promises being made by one side and too many unfounded hopes on the other. The opening of the museum has seen many important changes to the district's cultural calendar, but little else. Objectively, it would be too much to expect the creation of one museum to turn around the trends of several decades that have drained these peripheral rural areas both of their populations and economic opportunities.

The inclusion of Spanish Anchor Points into the ERIH has enabled these to become integrated into a cultural product of European scale, giving them greater international visibility. However, the quality of offerings within the ERIH is very variable-as the barometers mentioned seem to demonstrate-and despite attempts at integration, large differences remain between peripheral sites and those representing centres of industrial tourism. This is shown very clearly in our two case studies by the minimal numbers of international tourists recorded.

The mining industry in Almadén and Sabero closed due to environmental reasons. The ecological impact of the mercury and coal mines made these historic industrial spaces unsustainable. Years later, its transformation into a tourist attraction should have started with the environmental recovery of those areas.

Reality ultimately imposes itself onto theory. As a result, it is necessary to reflect on models of resilience for this type of territory. It appears to be justified to say that a cultural-tourism purpose is not sufficient to enable new productive processes to take off in many ex-industrial spaces, where there is a dominant narrative of depletion and high environmental impact [52]. 
Industrial tourism is not sustainable in locations far from centres of economic development, nor does it represent good practice in terms of territorial resilience where it is the only lever put in place to instigate development. It is not possible to make a fair comparison between the two examples mentioned here and places such as Ironbridge, Zollverein, New Lanark, Geselkirchen, Duisburg or Lowell. In all these cases, regeneration involved wholescale restoration of the environment, and of the social and cultural fabric of the region. In the Spanish examples, all that has been renovated are old mines and factories, which were declared to be cultural heritage sites shortly after their closure.

The only positive element that can be highlighted in both cases has been the promoting attitude of the public administration, which has sown hope in the local population, at least in the short term.

Industrial heritage tourism in Almadén and Sabero has not generated progress, nor innovation in accordance with Jansen-Verbeke's [21] definition of sustainability. They are exhibition centres visited for the most part by school parties on educational visits or by the elderly for recreation. They are not, however, motors for innovation or benchmarks for regenerating the productive fabric of these places. These targeted projects do not produce structural changes within a territory unless they are accompanied by many other initiatives, both public and private, that work together in a coordinated fashion to pursue a common goal.

This research presents a somewhat pessimistic conclusion, with many nuances that need to be explored through further case studies. In this way, within the context of other deindustrialised spaces, we may find the key to promoting sustainable and resilient regeneration.

Author Contributions: X.S.-M. is the author of Sections 1-3, 5.2, 6 and 7. O.M.-A. is the author of Sections 4 and 5.1. Both authors revised and corrected the entire text. All authors have read and agreed to the published version of the manuscript.

Funding: This research was funded by the Ministry of Science, Innovation and Universities of Spain, reference: RTI2018-095014-B-100 “Vulnerabilidad, resiliencia y estrategia de reutilización del patrimonio en espacios desindustrializados" (Vulnerability, resilience and reuse strategy for heritage in de-industrial spaces). Lead Researcher: Paz Benito del Pozo.

Data Availability Statement: www.erih.net.

Conflicts of Interest: The authors declare no conflict of interest.

\section{References}

1. Chmielewska, M. Conservation of post-industrial cultural heritage in Europe in local and global context. Reg. Reg. 2015, 12, 133-145.

2. Alonso, A.D.; O'Neill, M.A.; Kim, K. In search of authenticity: A case examination of the transformation of Alabama's Langdale Cotton Mill into an industrial heritage tourism attraction. J. Herit. Tour. 2010, 5, 33-48. [CrossRef]

3. Álvarez-Areces, M.A. Patrimonio industrial. Un futuro para el pasado desde la visión europea. Apuntes 2008, 21, 6-25. (In Spanish)

4. Hospers, G.-J. Industrial heritage tourism and regional restructuring in the European Union. Eur. Plan. Stud. 2002, 10, 397-404. [CrossRef]

5. Copic, S.; Djordjevica, J.; Lukic, T.; Stojanovic, V.; Djukicin, S.; Besermenji, S.; Stamenkovic, I.; Tumaric, A. Transformation of industrial heritage: An example of tourism industry development in the Ruhr area (Germany). Geogr. Pannon. 2014, 18, 43-50. [CrossRef]

6. Soyez, D. Europeanizing industrial heritage in europe: Addressing its transboundary and dark sides. Geogr. Z. 2009, 97, 43-55.

7. Asprogerakas, E.; Mountanea, K. Place branding and industrial heritage: Spatial strategies and interven-tions in the Ruhr area. In Proceedings of the 4th Annual Conference of the International Place Branding Association (IPBA), Volos, Greece, 27-29 November 2019.

8. Bangstad, T.R. Routes of industrial heritage: On the animation of sedentary objects. Cult. Unbound J. Curr. Cult. Res. 2011, 3, 279-294. [CrossRef]

9. Kruczek, Z.; Kruczek, M. Post-industrial tourism as a means to revitalize the environment of the former oil basin in the Polish Carpathian mountains. Pol. J. Environ. Stud. 2016, 25, 895-902. [CrossRef]

10. Holling, C.S. Resilience and stability of ecological systems. Annu. Rev. Ecol. Syst. 1973, 4, 1-23. [CrossRef]

11. Adger, W.N. Social and ecological resilience: Are they related? Prog. Hum. Geogr. 2000, 24, 347-364. [CrossRef]

12. Edwards, J.A.; Llurdés i Coit, J.C. Mines and quarries: Industrial heritage tourism. Ann. Tour. Res. 1996, 23, 341-363. [CrossRef] 
13. del Pozo, P.B. Dinamización del territorio y patrimonio industrial. Polígonos. Rev. Geogr. 1997, 7, 127-131. (In Spanish) [CrossRef]

14. Abad, C.J.P. Rutas y lugares de patrimonio industrial en Europa: Consideraciones sobre su aprovechamiento turístico. Espac. Tiempo Forma Ser. VI Geogr. 2002, 15, 69-94. (In Spanish) [CrossRef]

15. Cañizares Ruiz, M.D.C. Patrimonio minero-industrial en Castilla-La Mancha: El área Almadén-Puertollano. Investig. Geogr. 2003, 87. (In Spanish) [CrossRef]

16. Valenzuela Rubio, M.; Palacios García, A.J.; Hidalgo Giralt, C. La valorización turística del patrimonio minero en entornos rurales desfavorecidos: Actores y experiencias. Cuad. Tur. 2008, 22, 231-260. (In Spanish)

17. Barrado Timón, D.A.; Hidalgo Giralt, C.; Palacios García, A.J. Despoblación y envejecimiento en las zonas mineras. Es el turismo una solución? Casos de Riotinto y La Pernía-Barruelo. In Despoblación, Envejeci-Miento y Territorio: Un Análisis Sobre la Población Española; López Trigal, L., Abellán García, A., Godenau, D., Eds.; Universidad de León: León, España, 2009 ; pp. 629-642. (In Spanish)

18. Abad, C.J.P. Indicadores de sostenibilidad turística aplicados al patrimonio industrial y minero: Evaluación de resultados en algunos casos de estudio. BAGE 2014, 11-36. (In Spanish) [CrossRef]

19. Benito del Ponzo, P. Renovación urbana, herencia industrial y turismo: Un proceso con elementos de éxito en Avilés (Asturias). BAGE 2016, 285-304. (In Spanish) [CrossRef]

20. Giralt, C.H.; García, A.J.P.; Chamorro, V.F. La operatividad turística de los espacios culturales de origen industrial en Madrid. Un análisis de la oferta turística potencial mediante indicadores. Cuad. Tur. 2018, 295-321. (In Spanish) [CrossRef]

21. Jonsen-Verbeke, M. Industrial heritage: A nexus for sustainable tourism development. Tour. Geogr. 1999, 1, 70-85. [CrossRef]

22. Xie, P.F. Developing industrial heritage tourism: A case study of the proposed jeep museum in Toledo, Ohio. Tour. Manag. 2006, 27, 1321-1330. [CrossRef]

23. Cole, D. Exploring the sustainability of mining heritage tourism. J. Sustain. Tour. 2004, 12, 480-494. [CrossRef]

24. Contabilidad Regional de España. Available online: https://www.ine.es/dyngs/INEbase/es/operacion.htm?c=Estadistica_C\& cid=1254736167628\&menu=ultiDatos\&idp=1254735576581 (accessed on 19 July 2020). (In Spanish).

25. Tinoco, N.; Gómez, M. Heritage tourism and economic growth of the twenty most visited nations: A panel data analysis, 2006-2017. J. Tour. Herit. Res. 2019, 2, 120-135.

26. UNWTO. City Tourism and Culture; the European Experience; World Tourism Organization: Madrid, Spain, 2005.

27. Prat, J.M. El Turismo Industrial Como Elemento de Revalorización del Territorio: Un Análisis desde las Relaciones Sociales Presentes en los Destinos. Ph.D. Thesis, Universidad Autónoma de Barcelona, Barcelona, Spain, 2013. (In Spanish).

28. Lee, C.-F. Tourist satisfaction with factory tour experience. Int. J. Cult. Tour. Hosp. Res. 2015, 9, 261-277. [CrossRef]

29. MAYASA (grupo SEPI). Estudio de Visitantes en el Parque Minero de Almadén; SEPI: Madrid, Spain, 12 January 2019. (In Spanish)

30. Revisión del Padrón Municipal a 1 de Enero. Available online: https: / /www.ine.es/jaxiT3/Tabla.htm?t=2866\&L=0 (accessed on 11 July 2020). (In Spanish).

31. Palero, F.J. Aspectos geológicos y metalogénicos de los yacimientos de mercurio del distrito de Almadén (Ciudad Real). ReMetallica 2012, 19, 3-25. (In Spanish)

32. Palero, F.J.; Sánchez, C. Minerales de Castilla-La Mancha. In Patrimonio Geológico de Castilla-La Mancha; Nuche, R., Ed.; Enresa: Madrid, Spain, 2003; pp. 534-575.

33. Sánchez, J. Caminos históricos Toledo-Córdoba por el Valle de Alcudia. In Proceedings of the VII Congreso Internacional de Caminería Hispánica, Madrid, Spain, 2005; Centro de Estudios Históricos de Obras Públicas y Urbanismo: Madrid, Spain, 2006. (In Spanish)

34. Sumozas, R. Arquitectura Industrial en Almadén: Antecedentes, Génesis y Repercusión del Modelo en la Minería Americana; Universidad de Castilla-La Mancha: Ciudad Real, Spain; Universidad de Sevilla: Sevilla, Spain, 2007. (In Spanish)

35. Velasco, N. Una manifestación recorrerá Almadén bajo el lema ‘Del pozo se sale'. Lanza. Diario de La Mancha. 6 August 2019. Available online: https:/ / www.lanzadigital.com/provincia/almaden/una-manifestacion-recorrera-almaden-bajo-el-lema-delpozo-se-sale/ (accessed on 19 July 2020). (In Spanish).

36. Nace la Plataforma Forzados para canalizar las demandas emanadas del encierro-protesta de Almadén. El Diario. 3 November 2019. Available online: https:/ / www.eldiario.es/castilla-la-mancha/nace-plataforma-forzados-encierro-protesta-almaden_1_ 1371909.html (accessed on 19 July 2020). (In Spanish).

37. Mancomunidades Unidas para Frenar la Despoblación. La Tribuna de Ciudad Real. Available online: https://www. latribunadeciudadreal.es/noticia / ZE5576748-96C8-70E6-023D806460F1C84A/202002/Mancomunidades-unidas-para-frenarla-despoblacion (accessed on 19 July 2020). (In Spanish).

38. Álvarez, M.A. Patrimonio industrial, paisaje y desarrollo territorial. Areas Rev. Int. Cienc. Soc. 2010, 29, 21-29. (In Spanish)

39. Cañizares, M.C. El atractivo turístico de una de las minas de mercurio más importantes del mundo: El Parque Minero de Almadén (Ciudad Real). Cuad. Tur. 2008, 21, 9-31. (In Spanish)

40. Cañizares, M.C. The correct evaluation of the industrial mining heritage: The Mining Park of Almadén (World Heritage Site). In Patrimonio Cultural y Desarrollo Territorial; Reuters, A.T., Ed.; Thomson Reuters Aranzandi: Pamplona, Spain, 2016; pp. 339-369. (In Spanish)

41. Turismo Castilla-La Mancha. Available online: http:/ / www.turismocastillalamancha.es/plan-estrategico-turismo-castilla-lamancha-2020-2023.pdf (accessed on 17 July 2020).

42. Cañizares, M.C. Algunas iniciativas de turismo minero en Castilla-La Mancha. Cuad. Geogr. 2004, 34, $129-143$. 
43. Mansilla, L. El Parque Minero de Almadén. Un modelo de recuperación del patrimonio minero industrial. Her. Mus. 2011, 3, 13-24. (In Spanish)

44. Azuara, A.; del Río, I. Análisis turístico de Almadén (Ciudad Real). Propuestas de mejora en un entorno Patrimonio de la humanidad. ROTUR Rev. Ocio. Tur. 2016, 11, 22-34. (In Spanish)

45. Sanchez Muñoz, M.J. Los programas de desarrollo rural en la provincia de León. Polígonos Rev. Geogr. 2013, 151. (In Spanish) [CrossRef]

46. Botor, D.; Anczkiewicz, A.A. Thermal history of the Sabero Coalfield (Southern Cantabrian Zone, NW Spain) as revealed by apatite fission track analyses from tonstein horizons: Implications for timing of coalification. Acta Diabetol. 2015, 104, 1779-1793. [CrossRef]

47. Celemín Matachana, M.; Martínez Rodríguez, A. Recuperación económica de cuencas mineras y arqueología industrial. El caso de Sabero, León/España. Inf. Constr. 1997, 49, 41-48. (In Spanish) [CrossRef]

48. Sánchez Melado, J. Historia Económica de Una Cuenca Minera; Fundación EUGRAS: Valladolid, Spain, 2007.

49. Quirós Linares, F. La sociedad palentino-leonesa de minas y los primeros altos hornos al cok de España, en Sabero (1847-1862). Estud. Geogr. 1971, 32, 657-672. (In Spanish)

50. Quirós Linares, F. Santiago Alonso Cordero y la Ferrería de San Blas, en Sabero. Argutorio 2005, 15, 22-25. (In Spanish)

51. Vidal Encinas, J.; Álvarez Ordás, J.C. La protección del patrimonio arqueológico industrial en la provincia de León: El caso de la ferrería de San Blas, en Sabero. Tierras León 2003, 40, 95-122. (In Spanish)

52. Méndez, R. Desarrollo local en el capitalismo global: Un debate persistente. In Geografía y Ambiente Desde lo Local; Urquijo, P.S., Vieyra, A., Eds.; UNAM: Mexico City, Mexico, 2019; pp. 33-56. (In Spanish) 